UNITED STATES

DEPARTMENT OF THE INTERIOR

GEOLOGICAL SURVEY

GROUND-WATER HYDROLOGY OF THE TOPPENISH CREEK BASIN,

YARIMA INDIAN RESERVATION, WASHINGTON

By James A. Skrivan

U.S. GEOLOGICAL SURVEY

Water-Resources Investigations Report 82-4010

Prepared in cooperation with the

YARIMA TRIBAL COUNCIL

Tacoma, Washington

1987 


\section{UNITED STATES DEPARTIENT OF THE INTERIOR \\ DONALD PAUL HODEL, Secretary GEOLOGICAL SURVEY}

Dallas L. Peck, Director

Cover painting by Fred oldfield. Mr. Oldfield was born and ralsed on the Yakima Indian Reservation. Covers furnished by Yakima Tribal Council.

For additional information write to:

District Chief U.S. Geological Survey 1201 Pacific Avenue, Sulte 600 Tacoma, Washington 98402-4384
Coples of this report may be purchased from:

U. S. Geological Survey Books and Open-File Reports Federal Center, B1dg. 41 Box 25425

Denver, Colorado 80225

[Telephone: (303) 236-7476] 


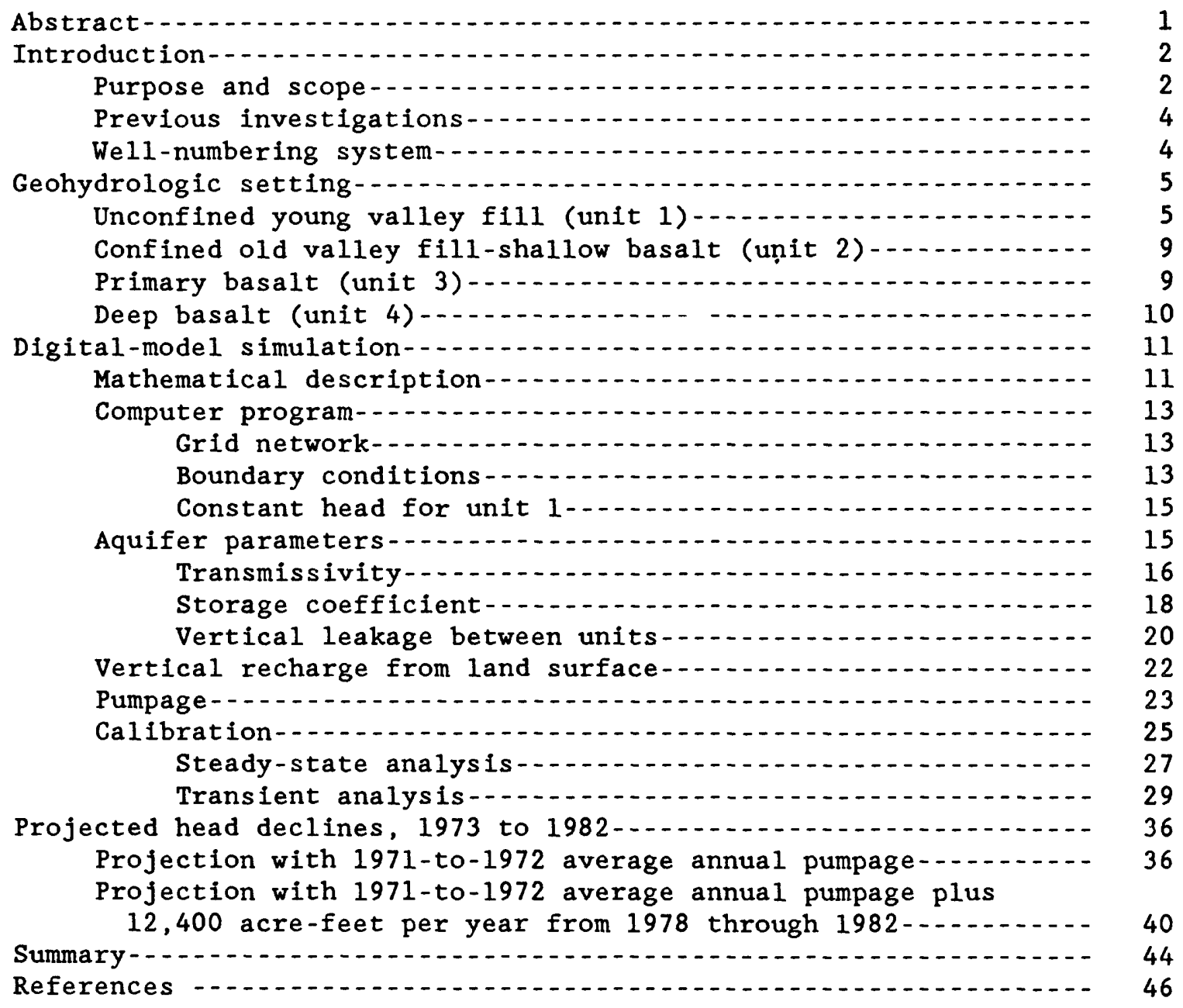


FIGURE 1. Oblique-view sketch showing topographic, cultural, and hydrologic features of the Toppenish Creek

basin-.... 3

2-3. Sketches showing:

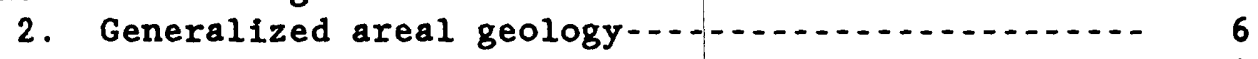

3. Four units of the aquifer system......... 8

4-12. Maps showing:

4. Finite-difference grid and boundary conditions used in the digital model... 14

5. Calibrated transmissivity distribution for units 2,3 , and 4. 17

6. Calibrated storage-coefficient distribution for units 2,3 , and 4 19

7. Calibrated leakance distribution for confining layers between adjacent units.............. 21

8. Calibrated vertical-recharge-rate distribution from land surface to unit 2... 24

9. Average annual pumpage distribution, 1971 to 1972

10. Heads in 1954 as a result of steady-state calibration of units 2,3 , and $4 \ldots . .28$

11. Head as a result of transient-state calibration of units 2,3 , and 4, December 1972 30

12. Comparison of measured and calculated 1960 to 1970 head decline in unit 3. 31

13-15. Hydrographs showing comparison of measured and computed drawdown at:

13. Node $(10,9,2) \ldots 32$

14. Nodes $(8,4,2)$ and $(5,8,3) \ldots \ldots$

15. Nodes $(3,10,3)$ and $(10,9,3) \ldots 33$

16. Calculated annual vertical leakage between units...... 35

17. Calculated annual depletion of ground water in storage in units 2, 3, and 4... 35

18-19. Maps showing:

18. Projected head decline from 1973 through 1977 in units 2, 3, and 4, using 1971 to 1972 average annual pumpage

19. Projected head decline from 1978 through 1982 in units 2, 3, and 4, using 1971 to 1972

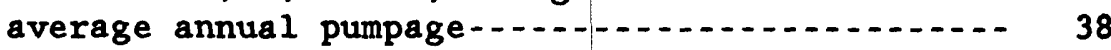

20. Projected drawdown from 1973 through 1982 at selected nodes, using 1971 to 1972 average annual pumpage-....- 
FIGURES 21-22. Maps showing:

21. Hypothetical pumping distribution, increasing 1971 to 1972 average

annual pumpage by 12,400 acre-feet-..... 41

22. Project head decline from 1978 through 1982 in units 2,3 , and 4, using 1971 to 1972 average annual pumpage plus 12,400 acre-feet per year....

23. Graph showing projected drawdown from 1973

through 1982 at selected lodes, using

1971 to 1972 average annual pumpage plus

12,400 acre-feet per year from 1978 through

1982

TABLES

Page

TABLE 1. Relation of geologic units to aquifer units-........ 7

2. Water budget for units 2,3 , and 4 for steady-state

(1954) conditions -

3. Water budget for units 2, 3, and 4 for 1972

4. Projected water budget for units 2,3 , and 4 for

1982, using 1971 to 1972 average annual pumpage......

5. Projected water budget for units 2,3 , and 4 , for

1982, using 1971 to 1972 average annual pumpage

plus 12,400 acre-feet per year from 1978 through

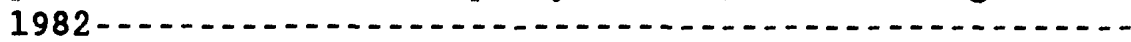




\section{METRIC (SI) CONVERSION FACTORS}

For the convenience of readers who may prefer to use metric (International System) units rather than the inch-pound units used in this report, values may be converted by using the following factors:

Multiply inch-pound units

by to obtain metric units

inch (In.)

inch per year (in./yr)

foot ( $f t$ )

square foot per day $\left(f t^{2} / d\right)$

mile (mi)

square mile $\left(\mathrm{mi}^{2}\right)$

acre

acre-foot (acre-ft)

acre-foot per year (acre-ft/yr)

gallon per minute per foot

(gal/min/ft)

\section{4}

2.540

25.4

0.3048

0.0929

1.609

2.590

4047.

1233.0

0.001233

1233.0

0.01242 millimeter (mm)

centimeter (cm)

millimeter per annum (mm/a)

meter ( $m$ )

square meter per day $\left(\mathrm{m}^{2} / d\right)$

kilometer $(\mathrm{km})$

square kilometer $\left(\mathrm{km}^{2}\right)$

square meter $\left(m^{2}\right)$

cubic meter ( $\left.\mathrm{m}^{3}\right)$

cubic hectometer $\left(\mathrm{hm}^{3}\right)$

cubic meter per annum $\left(\mathrm{m}^{3} / \mathrm{a}\right)$

cubic meter per minute per meter $\left(\mathrm{m}^{3} / \mathrm{min} / \mathrm{m}\right)$

National Geodetic Vertical Datum of 1929 (NGVD of 1929): A geodetic datum derived from a general adjustment of the first-order level nets of both the United States and Canada, formerly called mean sea level. 


\title{
GROUND-WATER HYDROLOGY OF THE TOPPENISH CREEK BASIN, YAKIMA INDIAN RESERVATION, WASHINGTON
}

\author{
By James A. Skrivan
}

\section{ABSTRACT}

A finite-difference ground-water flow model has been calibrated for the aquifer system in the Toppenish Creek basin, south-central Washington. The aquifer system consists of four units: (1) unconfined young valley fill; (2) confined old valley fill and shallow basalt; (3) primary basalt; and (4) deep basalt. The model simulated flow in units 2,3 , and 4 . In the eastern part of the basin, unit 1 was treated as having nstant water levels with time, but vertical leakage was simulated between units 1 and 2 .

Calibrated transmissivities for the three modeled units ranged from less than 0.01 to 0.48 square foot per second in the center of the basin.

Calibrated storage coefficients in the same area were 0.0004 to $0.006 .10^{\text {The }}$ leakance of the confining beds between aquifers ranged from $0.05 \times 10^{-10^{2}}$ to $2.5 \times 10^{-10}$ feet per second per foot.

Steady-state calibration was based on 1954 conditions, when pumping from unit 3 was less than 500 acre-feet per year. Under steady-state conditions, natural recharge was about 29,000 acre-feet per year from infiltration of precipitation in the western part of the basin and approximately 4,400 acrefeet per year of underflow from adjacent basins. Discharge under steady-state conditions was by means of underflow out of the basin to the east.

Transient-state calibration was based on the period 1955 to 1972 , during which time pumping increased about tenfold in unit 3. The 1971 to 1972 average annual pumpage was about 4,500 and 15,100 acre-feet from units 2 and 3 respectively. The increased pumpage rates, when used in the mode1, caused simulated declines in unit 3, in the middle of the basin, of as much as 60 feet from 1960 to 1970 .

Projected declines, using the 1971 to 1972 average annual pumpage, were computed for the periods 1973 to 1977 and 1978 to 1982 . The calculated annual drawdowns from 1973 to 1977 were 0.5 to 1.5 feet in unit 2 and 0.2 to 1.5 feet in unit 3 in the central part of the basin. The corresponding annual declines from 1978 to 1982 in the middle of the basin were 0.2 to 1.2 feet and 0.2 to 0.8 feet in units 2 and 3 , respectively.

Using 1971 to 1972 average annual pumpage plus an additional 12,400 acrefeet per year from unit 3, from 1978 through 1982, the calculated annual decline during that period was 1 to 6 feet in unit 2 and 4 to 20 feet in unit 3 . 


\section{INTRODUCTION}

The Toppenish Creek basin is on the eastern slope of the Cascade Range in south-central Washington ( $\mathrm{fig} .1$ ). Located entirely in Yakima County and having a drainage area of 627 square miles, the basin is the northernmost of three major river basins in the Yakima Indian Reservation; the other two are the Satus Creek basin to the south and the Klickitat River basin to the southwest. The altitude of the Toppenish Creek basin ranges from 5,100 feet in the mountains on the western drainage divide to about 750 feet on the eastern valley floor. Ahtanum and Toppenish Ridges form the basin's northern and southern boundaries, respectively. These ridges rise from the sagebrush plains and foothills to altitudes of 2,000 to 2,500 feet in the eastern half of the basin.

Irrigated agriculture is the major industry in the Toppenish Creek basin; approximately 120,000 acres are under cultivati... (Gregg and Laird, 1975). About 650,000 acre-feet of water are diverted annually from the Yakima River to supply water for most areas in the basin below the altitude of the Highline Canal (fig. 1).

Whereas higher land altitudes limit the use of diverted surface water without pumping stations, water for irrigation west and north of the Highline Canal is being pumped from the underlying basalt aquifers. Development of these aquifers has resulted in water-level declines greater than 75 feet in some areas since the 1950's. These declines have caused concern to the Yakima Indians regarding not only the possibility of depleting the basalt aquifers but also of lowering water levels in overlying aquifers.

Recognizing the need to evaluate various ground-water management alternatives, the Yakima Tribal Council entered into a cooperative agreement with the U.S. Geological Survey to simulate the effects of stresses on the ground-water system in the Toppenish Creek basin. This report documents the calibration of a model designed primarily to be used in the further development and management of the lower confined aquifers. An additional report (Bolke and Skrivan, 1981) describes the development of a more detailed model of the uppermost alluvial aquifer and its interconnection with the streams, canals, and drains in the basin.

\section{Purpose and Scope}

The purpose of this study was to (1) describe the hydrology of the aquifer system in the Toppenish Creek basin; and (2) construct a digitalcomputer model of the aquifer system to evaluate ground-water management alternatives.

The scope of the study was to (1) incorporate hydraulic parameters describing three aquifer units in a digital model to simulate flow within and between units; (2) calibrate the model; (3) determine water levels as a result of hypothetical stresses in two of the units; and (4) prepare a report which describes the resulting model and the effects of the stresses. 


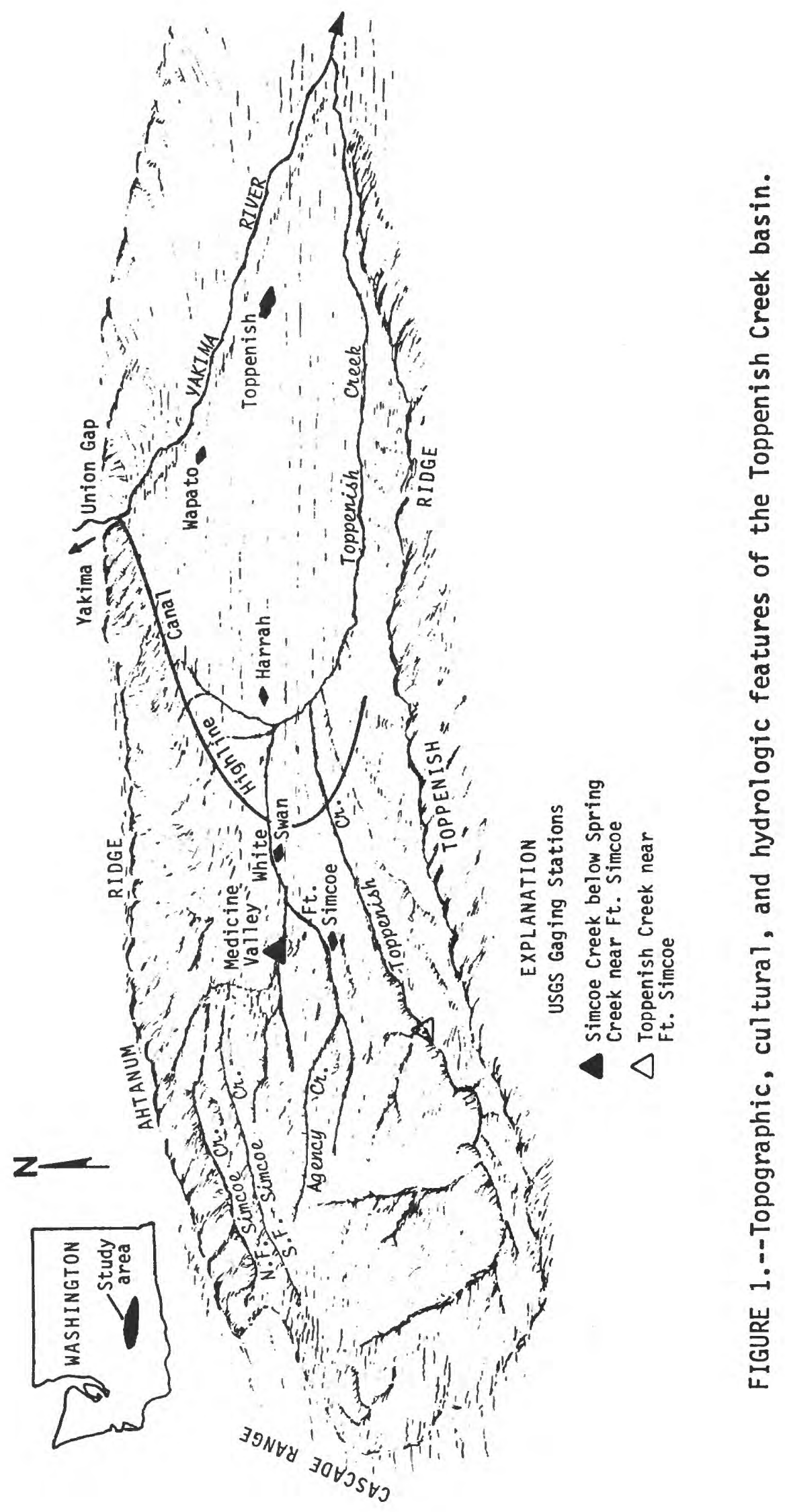


The model was calibrated using water levels in 1954, before significant pumping began in the basin, and water levels during the period 1955 to 1972 when ground-water pumpage for Irrigation increased dramatically. Water levels were then calculated for 1977 and 1982 on the basis of two hypothetical pumping distributions.

\section{Previous Investigations}

The earliest publication that contributes to the knowledge of the geohydrology of the basin was by Russell (1893). Smith (1901, 1903) and Waring (1913) described the geology of central Washington. More recent studies include the geohydrology of Ahtanum valley to the north of Toppenish Creek basin (Foxworthy, 1962) and an analysis of streamflow records in the Yakima River basin (Kinnison and Sceva, 1963). Gregg and Laird (1975) prepared a lay-reader report on water resources of the Toppenish Creek basin.

The most recent report on the basin was prepared by the U.S. Geological Survey (1975) and documents in a general manner the effects of surface-water and ground-water development. This comprehensive report supplied much of the data for the model described herein.

\section{We11-Numbering System}

In this report, wells are designated by symbols that indicate their locations according to the official rectangular system for the subdivision of public land. For example, in the well symbol 10/20-3M1, the part preceding the hyphen indicates, successively, the township and range (T.10 N., R.20 E.) north and east of the Willamette base line and meridian. Because the report area lies entirely north and east of the base line and meridian, the letters indicating the directions north and east are omitted. The first number following the hyphen indicates the section (sec. 3), and the letter "M" gives the 40-acre subdivision of the section, as shown in the diagram below. The numeral "1" indicates that this well is the first one listed in subdivision "M". 
A report by the U.S. Geological Survey (1975) describes the geohydrology of the Toppenish Creek basin, delineating three principal geologic units: (1) young valley fill; (2) old valley fill; and (3) basalt. Figure 2 shows the areal distribution of these three units in the basin.

The young valley fill includes alluvium and the upper part of the Ellensburg Formation of Miocene age (Smith, 1903), which consists of silt, sand, gravel, and cemented gravel, and reaches a maximum thickness of about 500 feet near Wapato (U.S. Geological Survey, 1975, p. 37). The old valley fill is primarily composed of partly consolidated silt, sand, gravel, and clay of the Ellensburg Formation. The old valley fill may reach a thickness of 1,000 feet near Wapato and Toppenish (Robbins and others, 1975, fig. 7).

The basalt is a layered sequence of lavas that underlies the entire Toppenish Creek basin. The maximum thickness is unknown, but the minimum is about 2,000 feet in the basin (Foxworthy, 1962).

The hydrology of the Toppenish Creek basin is complicated by the presence of multiple aquifer units, as well as by the interaction of surface water and ground water. Four aquifer units have been defined to facilitate modeling of the ground-water flow: (1) unconfined young valley fill; (2) confined old valley fill and shallow basalt; (3) primary basalt; and (4) deep basalt. 'rable 1 shows the relation of these aquifer units to the geologic units. Figure 3 is a sketch of the four aquifer units, showing the relation of one unit to the others as well as to the geographic features of the basin. U.S. Geological Survey Water-Resources Investigations Report 42-74 (1975) should be consulted for details of the geologic, lithologic, and water-yielding characteristics of the various aquifer units.

\section{Unconfined Young Valley Fill (Unit 1)}

The uppermost aquifer unit (unit 1) consists of those parts of the alluvium and Ellensburg Formation (U.S. Geological Survey, 1975, p. 37 to 59) which contain unconfined ground water (fig. 3).

The areal extent of unit 1 , as depicted in figure 3 , is less than that of units 2,3 , and 4 because this upper, unconfined unit occurs only in the eastern two-thirds of the basin.

Logs of wells penetrating the old valley fill indicate an extensive layer mostly of clay and silt from about 100 to 300 feet beneath the land surface of the interior lowland. This widespread layer, which apparently ranges from 50 to 200 feet in thickness, probably impedes the movement of water between units 1 and 2. The top of this clay-rich confining bed is, therefore, assumed to be the base of unit 1 (table 1 ). 


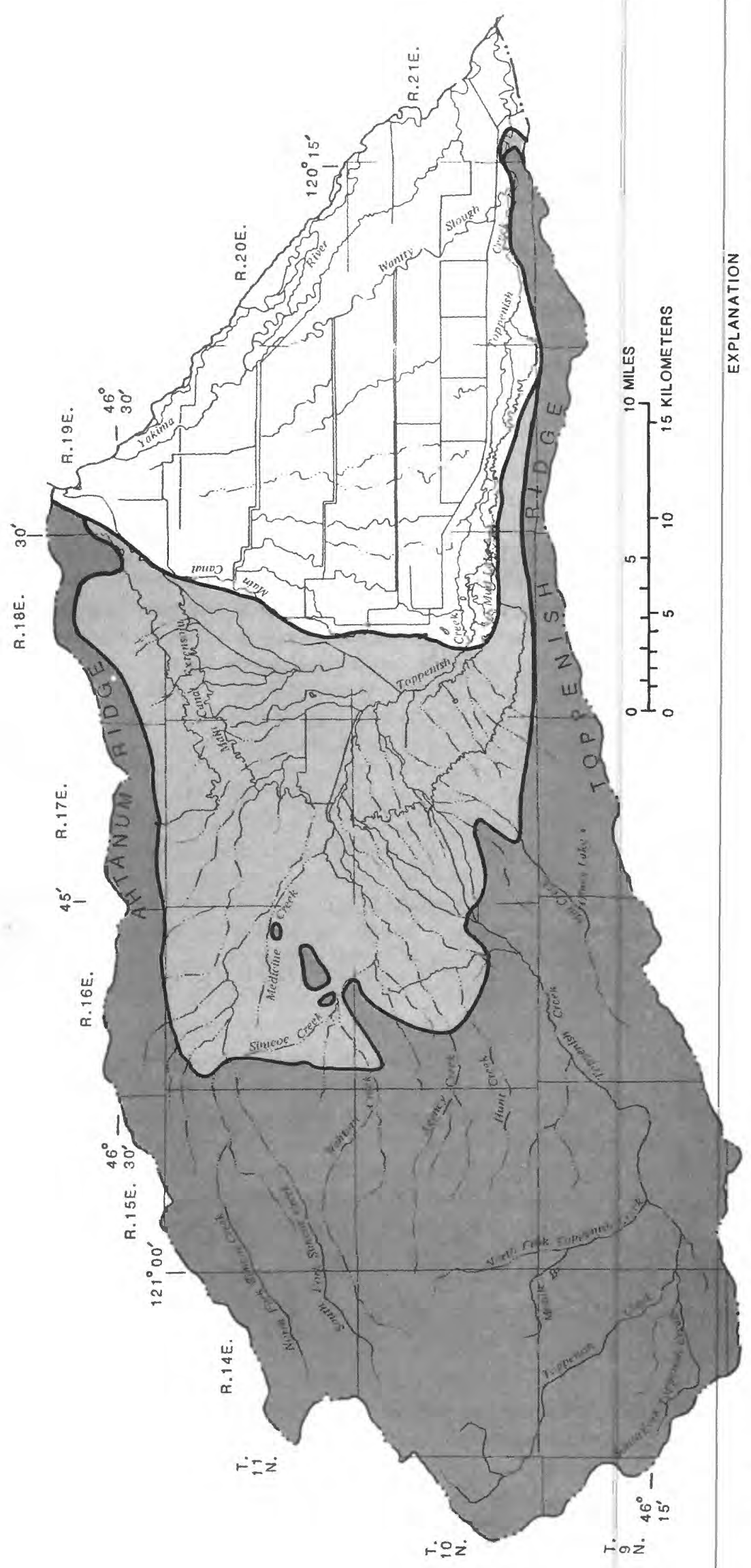

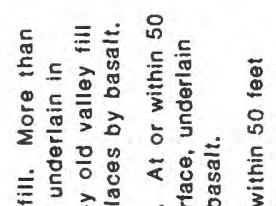

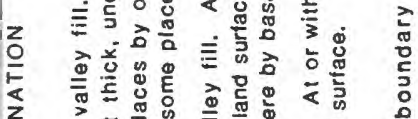

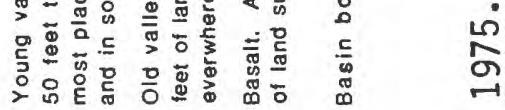

$\square \square \square$

गे

"ே.

i

$\dot{0}$

톤

ㅎํㅇ

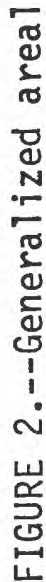

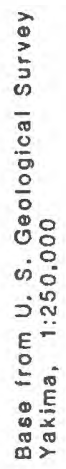


TABLE 1.--Relation of geologic units to aquifer units

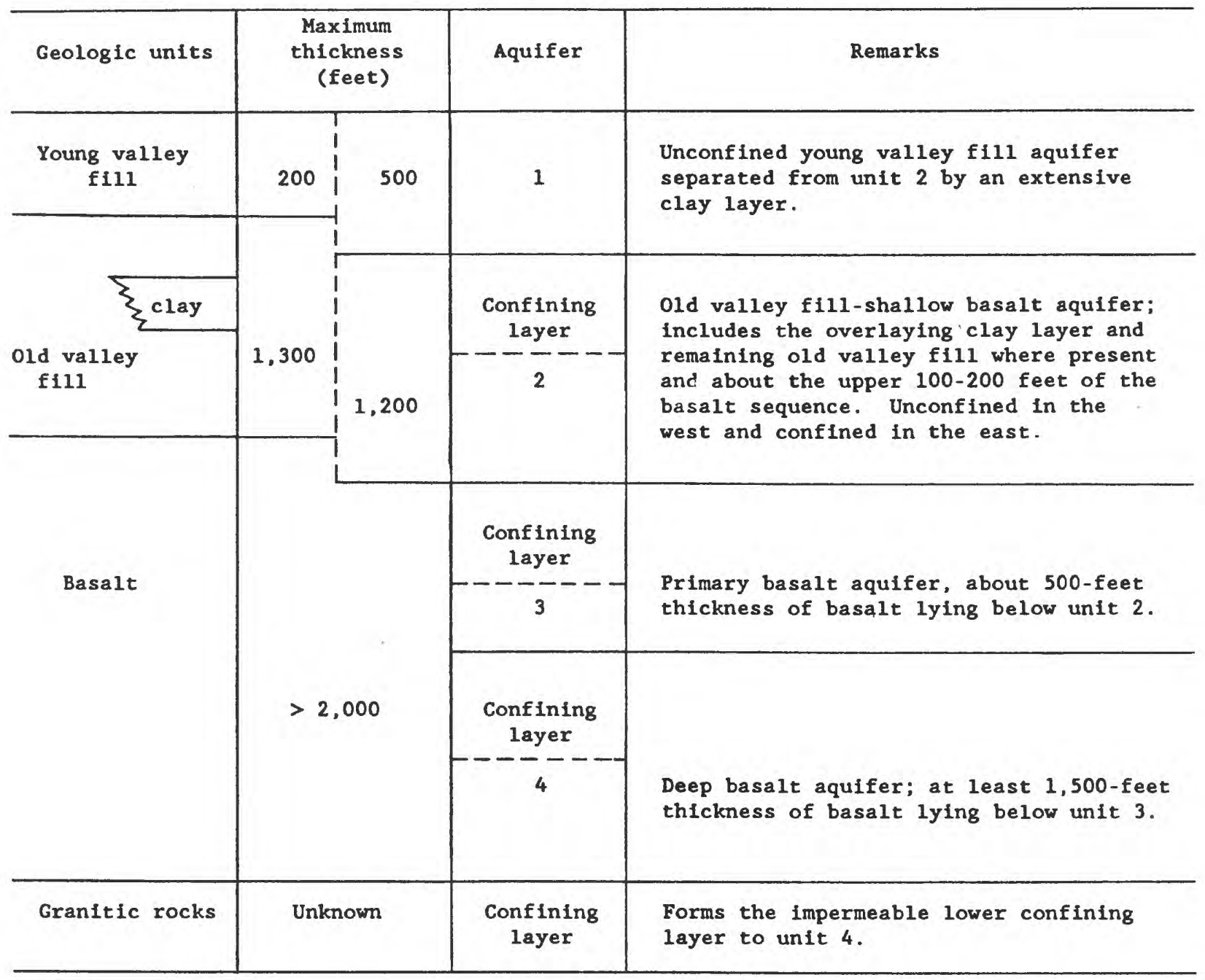




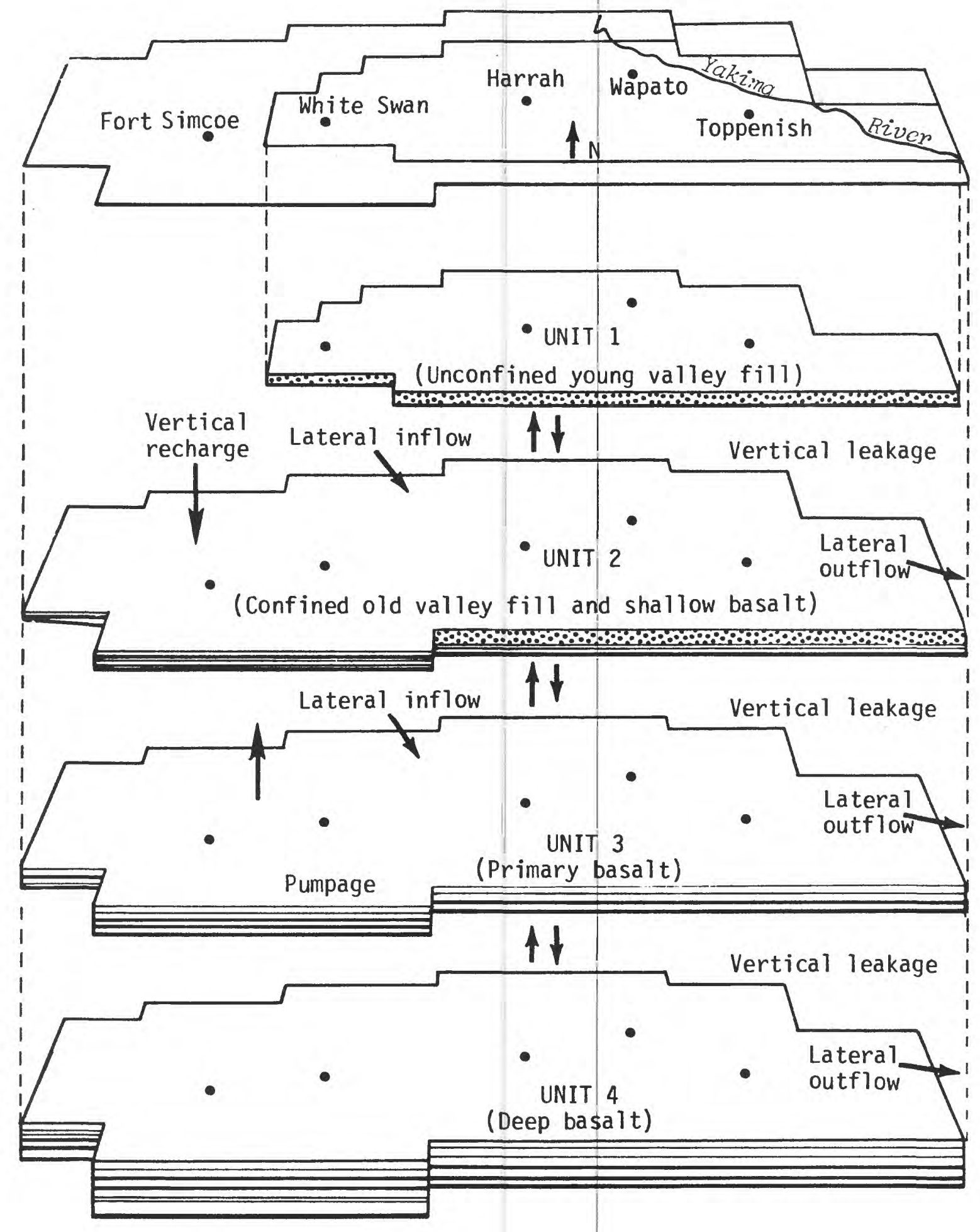

FIGURE 3.--The four units of the aquifer system. 
Annually, water levels in unit 1 fluctuate between low in the spring and high during late summer (U.S. Geological Survey, 1975, fig. 18). The greatest seasonal differences in water levels occur in the northern parts of the interior lowland, where as much as 15 feet of annual fluctuation is observed. The annual water-level change along the south edge of unit 1 is generally less than 5 feet (U.S. Geological Survey, 1975, fig. 19). Although the annual range in water levels in unit 1 varies from place to place, water levels at a given locality are at very nearly the same altitude at the same time every year. This cyclic nature of water-level change in unit 1 suggests that variations in hydraulic stresses and all reactions to those stresses are seasonal and similar from year to year.

\section{Confined Old Valley Fill-Shallow Basalt (Unit 2)}

The old valley fill (U.S. Geological Sirr ey, 1975, p. 52 to 59) is at or within 50 feet of land surface in the western part of the interior lowland of the basin and is overlain by the young valley fill in the eastern part of the basin (fig. 2). The clay bed within the old valley fill confines ground water in the old valley fill below the clay.

Observations of static heads and long-term head fluctuations in the shallowest basalt zones flanking the interior lowlands indicate consistency with those in the confined parts of the old valley fill (U.S. Geological Survey, 1975, table 2). However, heads from deeper basalt zones, which are delineated as primary basalt, or unit 3, indicate less consistency with confined heads in the old valley fill. This comparison suggests the existence of a separate hydrologic unit between unit 1 and the underlying primary basalt aquifer (unit 3 ).

Unit 2, then, includes the clay confining bed within the old valley fill, the deeper, confined part of the old valley fill, and the upper 100 to 200 feet of the basalt sequence underlying the basin (fig. 3). Because the basalt crops out or lies within 50 feet of land surface in about the western onethird of the basin (fig. 2), unit 2 consists of the shallow, unconfined basalt zones in the western one-third and the combined old valley fill-shallow basalt zones in the eastern two-thirds of the basin.

\section{Primary Basalt (Unit 3)}

The hydraulic characteristics of layered sequences of basaltic lavas of eastern Washington have been described by many previous investigators, including Newcomb (1959, 1961, 1965), Luzier and Burt (1974), Mac Nish and Barker (1976), and Barker (1979). Their conclusions may be summarized as follows. Tabular bodies of basalt representing individual flow units are stacked vertically over the entire Columbia River Plateau to depths of several thousand feet or more. Although the dense cores of the basalt flows are generally impermeable, the flow-contact zones are usually porous and much more permeable. The massive parts of basalt flows are often traversed by vertical narrow cracks that developed as the molten lava shrank upon cooling. Such cracks may provide avenues of ground-water movement between flows; however, 
movement through these vertical cracks occurs very slowly compared to the rates of lateral transmission in the flow-contact zones. Vertical hydraulic conductivities may be 7 or 8 orders of magnitude smaller than horizontal hydraulic conductivities (Mac Nish and Barker, 1976, p. 5). Consequently, the dense cores of flows often confine water in the flow-contact zones.

The primary basalt, modeled as unit 3 (f1g. 3), is approximately the upper 500 feet of the zone described in U.S. Geological Survey (1975) as, simply, the "basalt." This thickness of basalt is the zone tapped by deep wells in the basin. The upper and lower confining layers for unit 3 (table 1) are dense lava flows. However, such confining|layers in basalt aquifers are conceptual and normally not identiflable over a large areal extent.

\section{Deep Basalt (Unit 4)}

There is at least an additional 1,500-foot thickness of unexplored basalt below unit 3. (Granitic rock underlying the basalt is assumed to be impermeable.) Information about this deep basalt, or unit 4, had to be extrapolated from: (1) hydrologic knowledge about the deeper basalt strata elsewhere in eastern Washington (for example, Luzier and Burt, 1974, and Mac Nish and Barker, 1976); and (2) geohydrologic phenomena observed in the shallower basalt zones in the Toppenish Creek basin.

On the basis of this extrapolated information, the head in unit 4 in the western part of the basin is indicated to be lower, in general, than heads in the overlying units, and in the eastern part of the basin to be higher than heads in these units. Drilling experlence in the foothills region has normally shown that the head decreases as a well is drilled to greater depths (U.S. Geological Survey, 1975, p. 55).

These relative head differences were incorporated in the calibration process so that, in general, unit 4 is recharged in the western part of the basin and is discharged upward and laterally in the eastern part of the basin. If unit 4 were not included in the model as part of the aquifer system, unrealistically high transmissivities would be required in the upper three aquifer units to transmit the water that infiltrates in the upland recharge areas. 


\section{DIGITAL-MODEL SIMULATION}

In order to evaluate the quantitative aspects of the Toppenish basin aquifer system, as well as to predict future water levels, a digital-computer model was used to simulate ground-water flow. Calibration of such a model requires conceptualization of how the system operates, knowledge of the hydraulic properties of the system, and factual information about historic pumping and water levels.

Although the model is a simplification of the real system, future water levels can be predicted if the model is callbrated and verified using the pumping rates and water-level measurements made over a period of several years. This procedure involves changing the estimates of aquifer parameters to match more closely the measured and calculated water levels, first for steady-state (time-fixed) analysis, then for transient-state (time-variable) analysis. Once a close match is obtained, than water levels can be estimated for future arbitrary-pumping conditions. However, for these predictions to be valid, the cause-and-effect relations between pumping and water levels should not change significantly from the calibration period to the prediction period.

The model simulates ground-water flow in and between units 2,3 , and 4, and allows water levels to change as a function of recharge and discharge. Vertical leakage between units 1 and 2 is also simulated. Water levels in unit 1 are held constant at their average annual value, and recharge to and discharge from the upper surface of unit 1 are not simulated in the model.

The model is specifically designed to permit testing of alternative management schemes for units 2 and 3 only. The use of constant water levels in unit 1 requires that care be taken in using the model for proposed management schemes. Model-simulated pumpage in units 2 or 3 could induce more water from unit 1 into unit 2 than could actually be sustained in the real world. In addition, the model would tend to underpredict water-level declines in units 2 and 3 if the model-predicted induced recharge from unit 1 to 2 was sufficient to cause significant water-level declines in unit 1 . Bolke and Skrivan (1981) indicate that approximately 262,340 acre-feet of water is lost from unit 1 annually by evapotranspiration. Recapture of this water as a result of lowering ground-water levels in unit 1 is possible; this recapture would help limit the extent that ground-water levels in unit 1 would be lowered because of increased pumpage in units 2 or 3 .

\section{Mathematical Description}

Ground-water flow in three dimensions can be described mathematically by the following equation (Pinder, 1970):

$\frac{\delta}{\delta x} \frac{(\mathrm{T} \delta \mathrm{h})}{\delta \mathrm{x}}+\frac{\delta}{\delta \mathrm{y}} \frac{(\mathrm{T} \delta \mathrm{h})}{\delta \mathrm{y}}+\frac{\delta}{\delta \mathrm{z}} \frac{(\mathrm{Kb} \delta \mathrm{h})}{\delta \mathrm{z}}=\frac{\mathrm{S} \delta \mathrm{h}}{\delta \mathrm{t}}+\mathrm{W}+\mathrm{q}$


where $h=$ head, feet,

$T=$ transmissivity, square feet per second,

$\mathrm{b}=$ aquifer thickness, feet,

$\mathrm{K}=$ vertical hydraulic conductivity, feet per second,

$S$ - storage coefficlent, dimensionless,

$W=$ unit rate of withdrawal, feet per second,

$q=$ vertical flux, or leakage, feet per second,

$x, y, z=$ space coordinates, feet, and

$t=$ time, seconds.

Due to the amount of computations needed, a digital computer is required to solve this equation in large-scale or complex applications. However, even with a computer, such a solution can be time-consuming if estimates must be made of aquifer parameters that may vary with vertical and horizontal

position. A means to ease this problem was propbsed by Bredehoeft and Pinder (1970). The three-dimensional aquifer system is approximated by layered, horizontally dimensioned aquifers separated by confining layers. Heads are calculated for each aquifer unit on the basis of horizontally var able aquifer parameters and vertical leakage between that aquifer and adjacent ones.

As applied to the Toppenish Creek basin, the approximation uses a twodimensional equation to describe horizontal ground-water flow in each of three aquifer units, 2,3 , and 4 , and vertical leakage between units 1 and 2,2 and 3 , and 3 and 4 .

The resulting equation for each of the three units is:

$$
\begin{aligned}
& \frac{\delta}{\delta x} \frac{\left(T_{1} \delta h_{1}\right)}{\delta x}+\frac{\delta}{\delta y} \frac{\left(T_{1} \delta h_{1}\right)}{\delta y}=s_{i} \frac{\delta h_{1}}{\delta t}+w_{i}+q_{1, i+1}-q_{i, i-1} \\
& \text { for unit } 1=2,3,4
\end{aligned}
$$

where $h_{f}, T, S_{1}$, and $w_{i}$ refer to head, transmissivity, storage coefficient and unit withdrawal, respectively, for unit $i$. In addition, $q_{i}$ is the vertical leakage from unit $i$ to unit $i+1$, and $q_{i} i_{1-1}$ is the vertictal leakage to unit 1-1 from unit 1 . The term $q_{4}$ is defined as zero because there is assumed no vertical leakage between unit 4 and the underlying granitic rocks.

Vertical leakage, $q_{i, 1+1}$, is head dependent and defined as:

$$
\mathrm{q}_{i, i+1}=\frac{\mathrm{k}_{1}}{\mathrm{~m}_{i}}\left(\mathrm{~h}_{i}-\mathrm{h}_{i+1}\right)
$$

where $\mathrm{K}_{1}$ is the vertical hydraulic conductivity and $\mathrm{m}_{1}$ is the thickness of the confining layer separating units 1 and $1+1$, and $h$ and $h$ are the heads in units $i$ and $i+1$, respectively. Hydraulic conductfvity $i \frac{1}{s}+\frac{1}{a}$ measure of the ability of the aquifer to transmit water in unit time due to a unit head gradient. The ratio $\mathrm{K}_{1} / \mathrm{m}_{\mathrm{i}}$ is commonly called the leakance. 
Heads are calculated for each unit as a function of time and horizontal location. In general, heads depend on lateral flow in each aquifer unit, vertical leakage between units, change in ground-water storage, and the amount of discharge and (or) recharge to each unit.

\section{Computer Program}

The digital model of ground-water flow in the Toppenish Creek basin is based on a computer program by Trescott (1975). This model uses an iterative, numerical technique to calculate heads by solving sets of simultaneous equations as a result of finite-difference approximations to equation 2 for each unit. Water-level-change maps can be prepared from beginning and ending calculated heads. Hydrographs, or plots of water levels at a particular point at various times, can also be prepared from calculated heads. Conditions for computer solution include establishing a $g^{*}$ network and specifying initial heads and boundary conditions.

\section{Grid Network}

A finite-difference approximation requires that the areal extent of the aquifer system be overlain by a grid of rectangles (fig. 4). The center of each rectangle, or element, is a node. A particular element or node is specified, as shown in figure 4 , by the numbers $(i, j, k)$, where $i$ and $j$ are the row and column numbers, respectively, and $k$ is the aquifer unit number. Aquifer parameters such as transmissivity and storage coefficient are specified for each element and an initial head is specified at each node. Parameters are assumed to be homogeneous throughout each element.

Near the west-central part of the basin, square elements with 2 -mile sides are used. Toward the edges of the model, however, elements become progressively larger and reach a maximum size of 2 miles by 6 miles. The square elements with 2 -mile sides are used in the areas of pumping and the larger elements are used in surrounding areas.

\section{Boundary Conditions}

The solution of equation 2 requires that the part of the aquifer system modeled be bounded on the top, sides, and bottom. Natural boundaries such as no-flow boundaries at impermeable bedrock or constant-head boundaries at a stream or lake are typical conditions used in ground-water flow models. Another possible boundary condition is constant flux (constant hydraulic gradient), by which lateral flow into or out of an element is specified. This condition is often used when a natural hydrologic boundary is too far away from the modeled area to be included. 


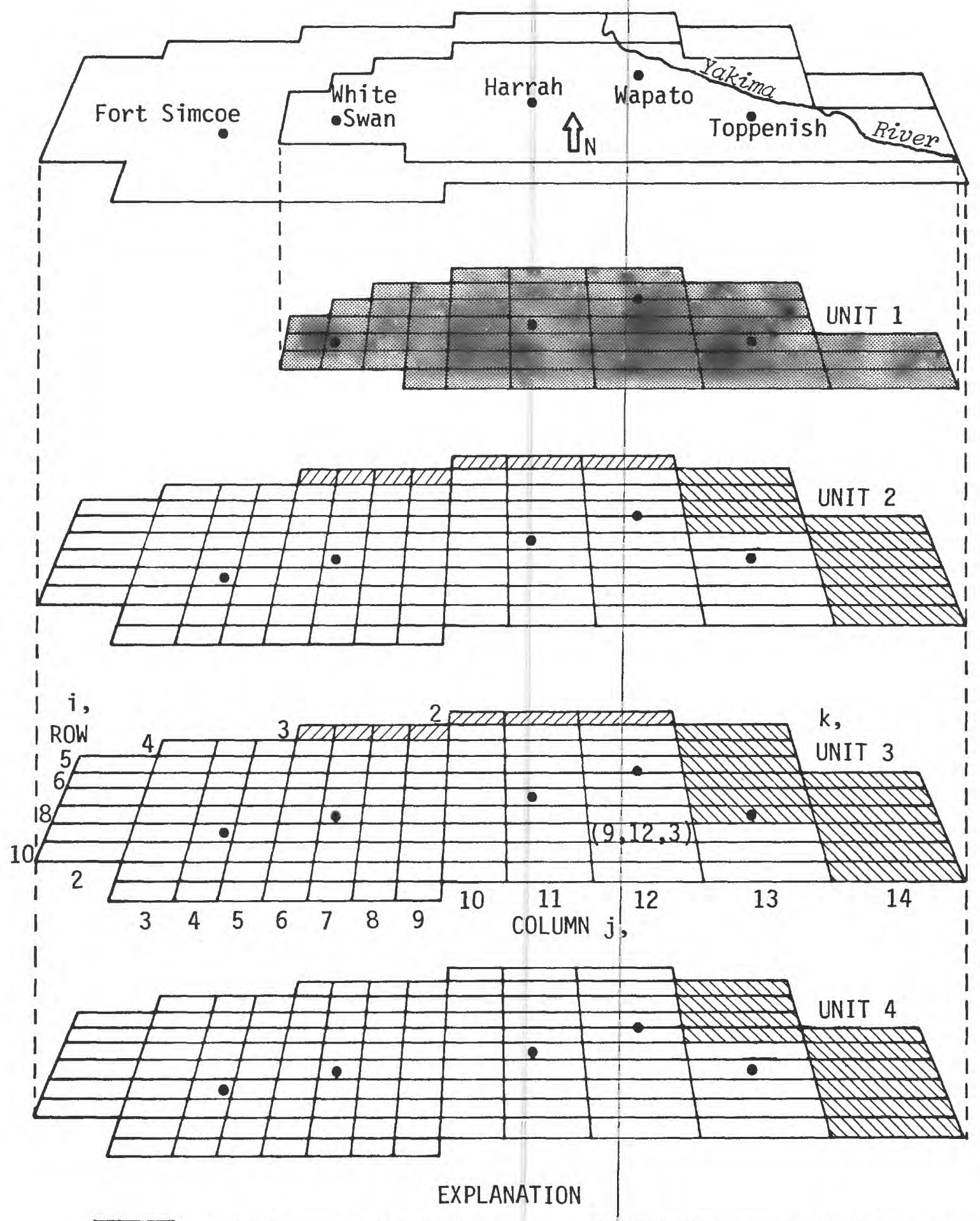

Constant-head boundary $\quad(9,12,3)$ is node number $i, j, k$
Constant-flux boundary

QDIT Constarit-head boundary for steady-state simulation; changed to constant-flux boundary for transient state.

FIGURE 4.--Finite-difference grid and boundary conditions used in the digital model. 
The boundary conditions for the modeled aquifer system are shown in figure 4. A no-flow boundary is assumed unless specified otherwise. The constant-flux boundary on the eastern edges of units 2,3 , and 4 represents lateral underflow out of the modeled area. The nodes along the middle of the northern edge of units 2 and 3 simulate lateral underflow into the basin as constant-head boundaries in the steady-state analysis and as constant-flux boundaries in the transient analysis, in both cases at identical flow magnitudes.

The constant-flux boundary used in transient-state calibration and projections is an approximation of a hydrologic system in which the amount of underflow may change with changing water levels at or near the boundary. Thus, this approximation is satisfactory only if measured water levels do not change appreciably over time near the boundary nodes.

\section{Constant Head for Unit 1}

The interaction of surface water and ground water occurs within a few tens of feet of land surface in unit 1. In spite of the complexities inherent in the hydrology of unit 1, however, the net effect of this interaction is that the seasonal patterns of water-level rise and fall are cyclic and are almost exactly repeated year after year (U.S. Geological Survey, 1975). These predictable patterns of water-level response (owing to seasonally oriented activities such as irrigation, precipitation, evapotranspiration, and surface drainage) are not likely to change during the next decade or longer.

Holding water levels in unit 1 constant at their average annual altitudes during calibration eliminates the need to simulate all the separate exchanges of water as a result of the processes of precipitation, irrigation, evapotranpiration, runoff, and surface drainage. Because the net effect of all these processes is small in unit 1 (seasonal water-level fluctuations of 15 feet or less), their effect on unit 2 should be minimal. Thus, for the purpose of calibration, the vertical flux between units 1 and 2 is assumed to be approximated adequately if changes in the head differential between these units are made to depend only on head changes simulated in unit 2 .

\section{Aquifer Parameters}

To solve equation 2 for heads in units 2,3 , and 4 , estimates are needed for transmissivity and storage coefficient for each unit and vertical leakage between all adjacent units. Estimates for those parameters are available from aquifer tests in Toppenish Creek basin and model studies of similar basins. Units 2, 3, and 4 are considered heterogeneous but isotropic; that is, the aquifer parameters vary with location but not with direction of flow.

As described in the following sections, the initial estimates of aquifer parameters that were incorporated in the first computer runs were refined to final estimates as a result of the calibration process. 
Transmissivity (T) is a major factor controlling the rate of water movement through an aquifer and is a function of permeability and saturated thickness of each distinct stratum within an aquifer.

Unit 2 is a combination of shallow basalt to the west and confined old valley fill underlain by shallow basalt to the east. The area in which the old valley fill lies at or within 50 feet of land surface is shown in figure 2. The initial values for $T$ are based primarily on information in U.S. Geological Survey (1975). In addition, by using a method to estimate T described by Theis and others (1963) from speciffc capacity (pumping rate per foot of drawdown), T was estimated to be $0.09 \mathrm{ft}^{2} / \mathrm{s}$ for most of the eastern region of unit 2, where the old valley fill is approximately 1,000 feet thick. Smaller $T$ values were used in the west-centr. 1 part because the old valley fill thins to the west.

Estimates of $T$ for the shallow basalt of unit 2 are not as supportive as those for the old valley fill. The thickness of basalt included with unit 2 was arbitrarily chosen as 100 to 200 feet, and no aquifer-test data are avallable for wells tapping this zone. Consequently, initial $T$ estimates, where the basalt is at or within 50 feet of land surface (fig. 2), were also chosen arbitrarily. The values selected for the basalt were less than those for the old valley fill because of less permeability and saturated thickness. Several elements in the western part of the basin were assigned low $T$ values because of an apparent ground-water barrier that affects upper basalt zones (U.S. Geological Survey, 1875, p. 60). The final calibrated T distribution for unit 2 used in the mode1, as a result of the calibration process (see p. 25), is given in figure 5, the range in transmissivities being from less than 0.01 to $0.10 \mathrm{ft}^{2} / \mathrm{s}$.

Initial T estimates for unit 3 , the primary basalt aquifer, were made from both aquifer tests and eastern Washington basalt model studies. Reported specific capacities for unit 3 range from less than 1 to $400(\mathrm{gal} / \mathrm{m}) / \mathrm{ft}$ of drawdown (U.S. Geological Survey, 1975). These specific capacities yield $T$ estimates of about 0.003 to $1.24 \mathrm{ft}^{2} / \mathrm{s}$.

Calibrated $T$ values for a digital model of a similar pasalt aquifer in the Walla Walla basin ranged from 0.01 to more than $0.5 \mathrm{ft}^{2} / \mathrm{s}$ (Mac Nish and Barker, 1976). Similarly, T values for the Odessa-Lind basalt aquifer model (Luzier and Skrivan, 1975) were 0.003 to $0.45 \mathrm{ft}^{2} / \mathrm{s}$. The calibrated T distribution used in the Pullman-Moscow basalt aquifer model ranged from 0.001 to $0.325 \mathrm{ft}^{2} / \mathrm{s}$ (Barker, 1979).

The final calibrated $T$ values for unit 3 , as shown in figure 5 , range from less than 0.01 to $0.20 \mathrm{ft}^{2} / \mathrm{s}$. Lower values of $T$ along the northern and southern boundaries correspond to impeded ground-water flow across Ahtanum and Toppenish Ridges, respectively. Ahtanum Ridge is a structurally tight, asymmetrical anticlinal fold, as evidenced at Union Gap (Foxworthy, 1962). This 

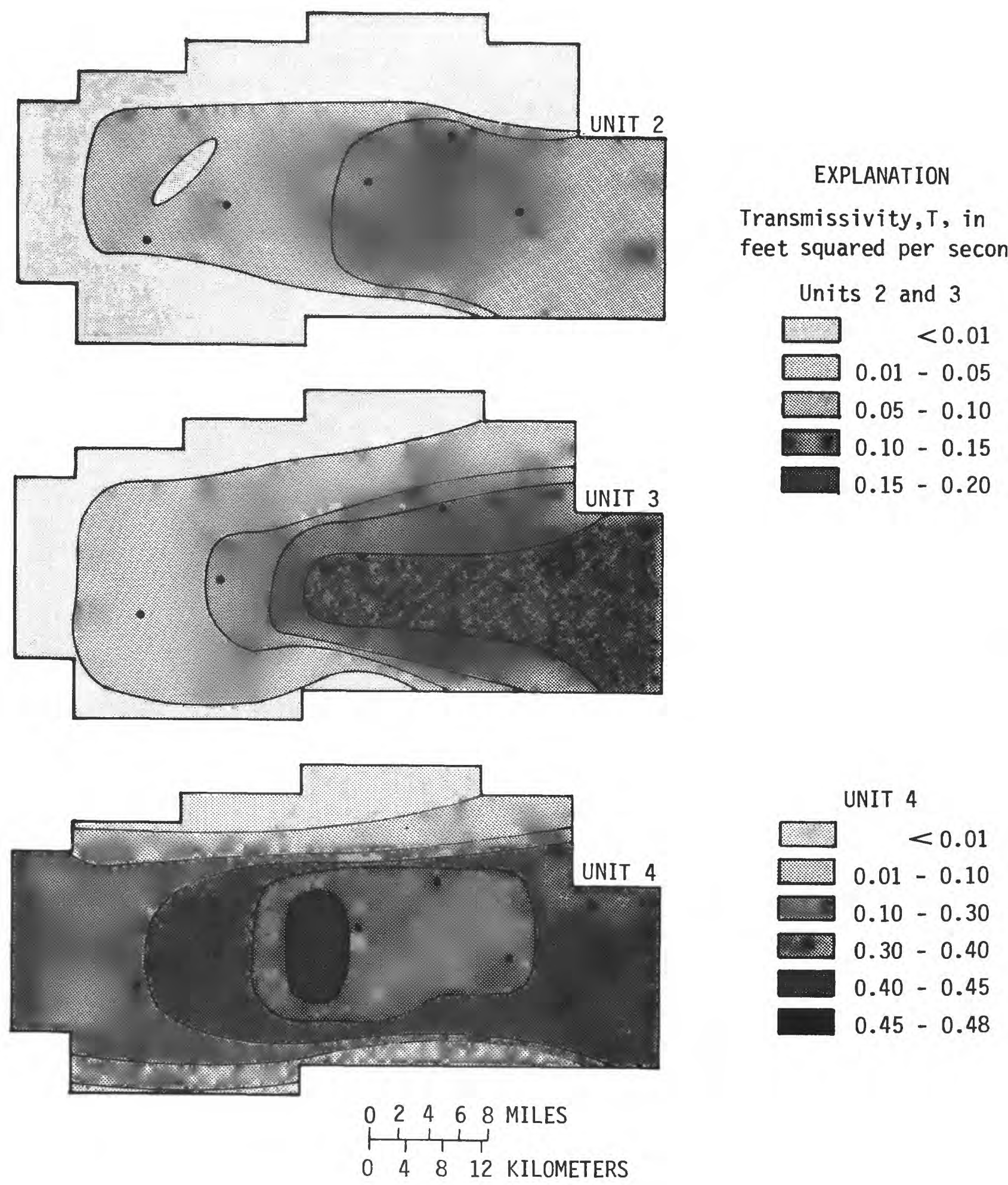

FIGURE 5.--Calibrated transmissivity, T, distribution for units 2,3 , and 4. 
folding undoubtedly impedes ground-water flow because of the discontinuous nature of the interflow zones. Water-level measurements in the Ahtanum-Moxee basin, just north of Toppenish basin, indicate steep head gradients, which are usually indicative of ground-water barriers, across Ahtanum Ridge. Lower $T$ values in the western part of unit 3 correspond to a thinning of basalt flows there.

Unit 4 includes the deep basalt which underlies the primary basalt aquifer (unit 3) just described. The thickness of unit 4 is probably at least 1,500 feet, or about 3 times or more the thickness of unit 3 . Because no wells in the basin penetrate unit 4, there are no aquifer tests available to give estimates of transmissivity. Based on relative thicknesses of basalt and estimates of $T$ from ynit 3, the initial $T$ value for unit 4 was estimated to approximately $0.3 \mathrm{ft} / \mathrm{s}$. The final calibrated $T$ distribution for unit 4 is shown in figure 5; $T$ values range from less han 0.01 to about $0.5 \mathrm{ft} / \mathrm{s}$. The areal pattern is similar to that for unit 3 , in that lower $T$ values occur along Ahtanum and Toppenish Ridges. In the western part of the basin, however, $T$ values for unit 4 are greater than those for unit 3 because of probably increased saturated thickness of unit 4 compared with unit 3 in that area.

\section{Storage Coefficient}

The storage coefficient (S) describes an aquifer's ability to release or store water. For an unconfined aquifer, $S$ usually varies from 0.02 to 0.3 . The coefficient of storage for a confined aquifer is less than that for an unconfined aquifer. It is a function of aquifer thickness, porosity, aquifer skeleton, and the elasticity and specific weight of water. Owing to the possible range in these variables, the coefficient of storage for confined aquifers can vary widely. Walton (1970) indicates that values generally range between 0.00001 and 0.001 , but exceptions are common.

No previous estimates of $S$ for the old valley fill were available. However, preliminary values of $S$ for the basalt were obtained from previous model studies of basalt aquifers. For example, the Odessa-Lind basalt model used S values between 0.0015 and 0.006 (Luzier and Skrivan, 1975); S of 0.0025 was used for the Columbla Basin irrigation project model (Tanaka and others, 1974). An $S$ value of 0.00048 was incorporated for most of the basalt aquifer of the Walla Walla basin (Mac Nish and Barker, 1976). With the exception of the Walla Walla basalt aquifer model, these values of $S$ are larger than might be expected for a confined aquifer. One explanation might be that more vertical leakage is present in nature than in the models. Another reason is that the basalt aquifers may become unconfined as water levels drop below the bottom of a thick, dense section of basalt. The final calibrated storage coefficients for units 2,3 , and 4 , as a result of the calibration process (see p. 25), are shown in figure 6 . 

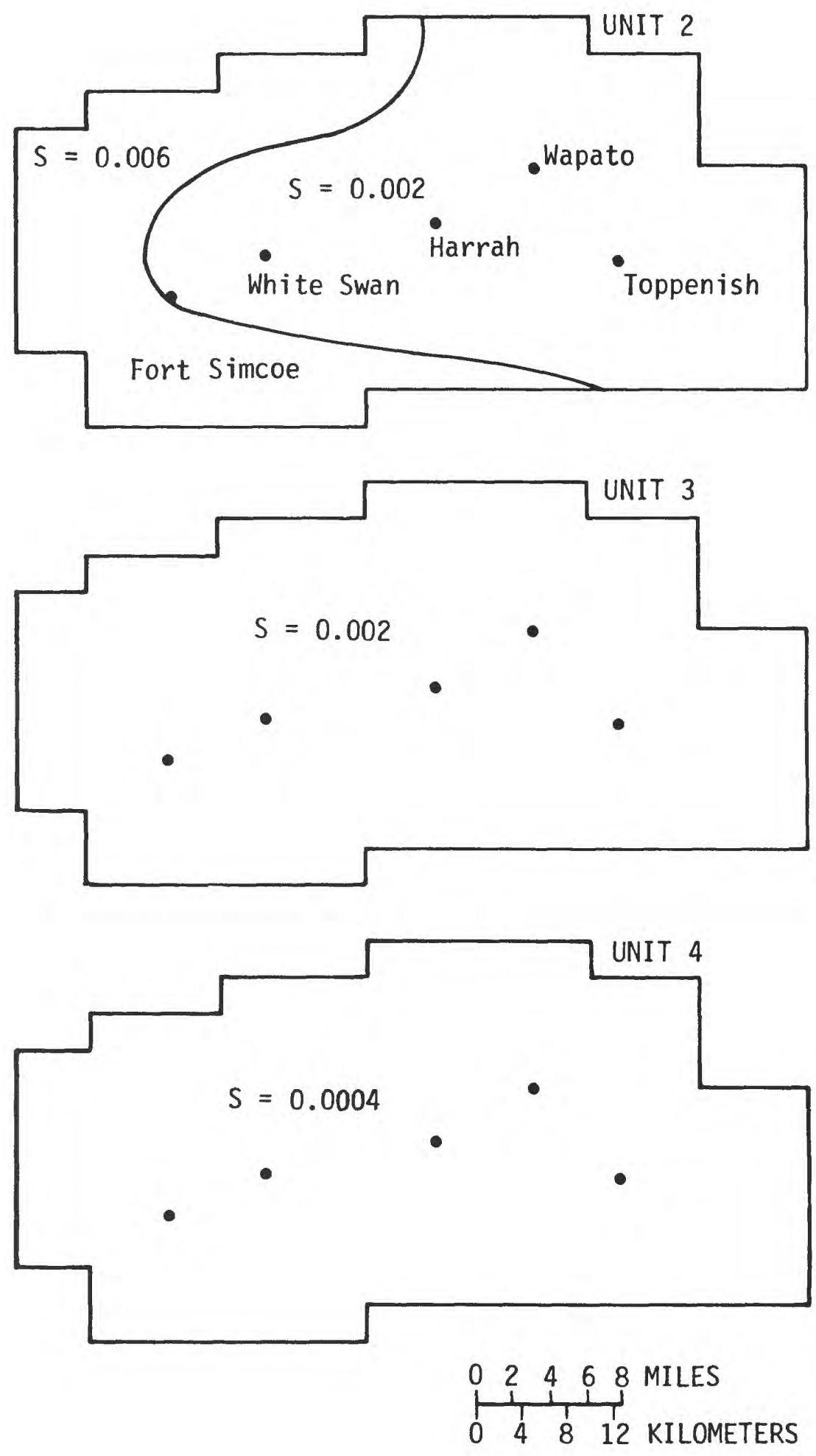

FIGURE 6.--Calibrated storage-coefficient $(S)$ distribution for units 2,3 , and 4 . 
Units $1,2,3$, and 4 are interconnected by the vertical movement of water between adjacent units. Since units 2, 3, and 4 are partially or completely confined aquifers, each has an upper and lower confining bed or layer which retards vertical flow (see table 1). Except for the impermeable granitic rocks underlying unit 4 , all confining layers allow vertical movement of water if there is a head gradlent across them. This/vertical flux represents significant inflow and (or) outflow for all the units.

Vertical leakage is computed with equation 3, which involves the leakance $\mathrm{K}_{i} / \mathrm{m}_{i}$, where $\mathrm{K}_{f}$ is the vertical hydraulic conductivity and $\mathrm{m}_{i}$ is the thickness of the confining layer between units 1 and $1+1$. The leakance parameter can be varied in the calibration process to match calculated heads to measured heads more closely.

Estimates for $\mathrm{K}_{1} / \mathrm{m}_{1}$, which is the leakance for the clay confining layer between units 1 and 2 , are given in U.S. Geological Survey (1975) -10 For $m$, betwen 50 and 200 feet, estimates for $k_{1} / m_{1}$ range between $5 \times 10^{-10^{-}}$and $20 \times$ $10^{-10}(\mathrm{ft} / \mathrm{s}) / \mathrm{ft}$. The final calibrated distribution for leakange between uniff 1 and 2 is given in figure 7; the values range from $0.1 \times 10^{-10^{2}}$ to $2.5 \times 10^{-10}$ (ft/s)/ft.

The outline in figure 7 for the confining layer between units 1 and 2 represents the areal extent common to both of these units. West of unit 1 , unit 2 is unconfined and receives vertical recharge from the infiltration of precipitation. Vertical recharge is discussed on page 22.

The remaining confining layers for units 2,3 , and 4 are in basalt, except for the lower confining layer of unit 4 in granitic rocks (table 1 ). Other basalt-model studies have considered these basalt confining layers to be composed of at least one dense basaltic flow (for example, see luzier and Skrivan, 1975). Because the thicknesses of these basalt confining layers are unknown for this model, $\mathrm{k} / \mathrm{m}$ for each of those layers is treated as a single parameter, so that $m$ (thickness) by itself does not need to be estimated.

Model studies in other basins in eastern Washington were used to make initial estimates of $\mathrm{k} / \mathrm{m}$ for basalt confining layers in the Toppenish basin. For example, $\mathrm{K} / \mathrm{m}$ in the Pullman-Moscow basalt mpdel ranged from $4 \times 10^{-12}$ to $2 \times 10^{-9}(\mathrm{ft} / \mathrm{s}) / \mathrm{ft}$, and averaged about $1-10^{-1}(\mathrm{ft} / \mathrm{s}) / \mathrm{ft}$ (Barker, 1979). In the Odessa-Lind model, $\mathrm{k} / \mathrm{m}$ was $1.5 \times 10^{-10}(\mathrm{ft} / \mathrm{s}$ )/ft (Luzier and Skrivan, 1975).

The final calibrated distribution for $\mathrm{k}_{2} / \mathrm{m}_{2}$, the leakance for the confining layer $1 f^{\text {etween units }} 20^{\text {and } 3, \text { is }}$ given in figure 7 . The values range from $0.05 \times 10^{-10^{2}}$ to $0.8 \times 10^{-10^{2}}(\mathrm{ft} / \mathrm{s}) / \mathrm{ft}$. Figure 7 also shows the corresponding final values of $\mathrm{K}_{3} / \mathrm{m}_{3}$, the leakance for the confining layer between unjts 3 and 4 . The range of calibrated $x_{3} / m_{3}$ is from $0.2 \times 10^{-10}$ to $0.4 \times 10^{-10}(\mathrm{ft} / \mathrm{s}) / \mathrm{ft}$. 


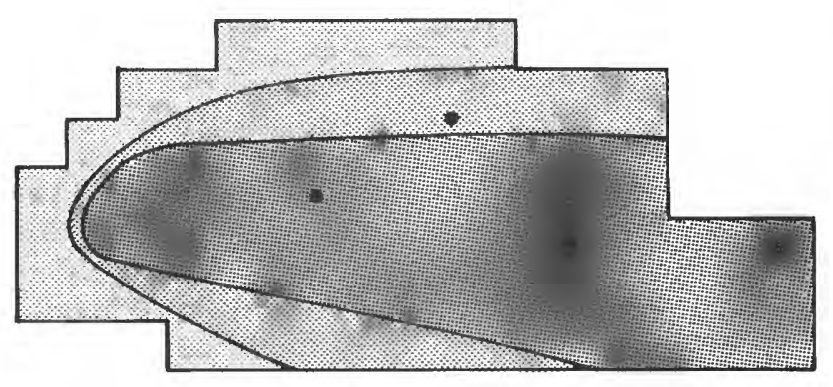

EXPLANATION Leakance $(\mathrm{K} / \mathrm{m})$ in feet
per second per foot $\times 10^{-10}$

Confining layer between units 1 and 2

$0.1-1.0$
$1.0-2.0$
$2.0-2.5$

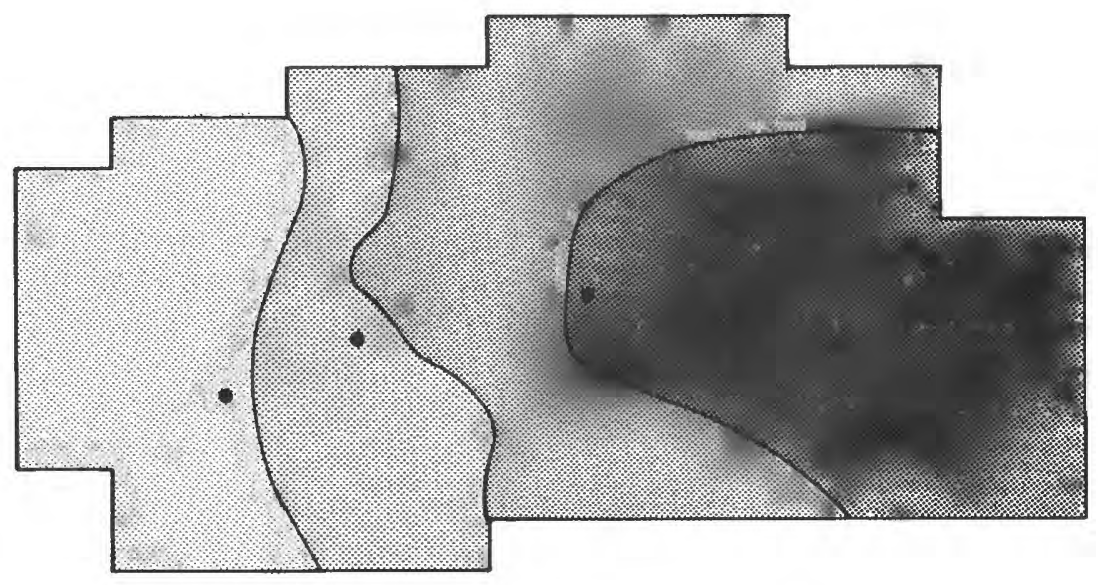

Confining layer between units 2 and 3

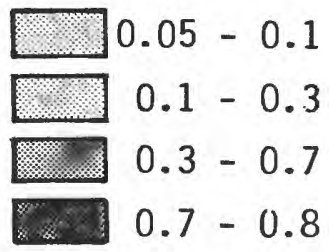

Confining layer between units 3 and 4

$0.2-0.3$

$0.3-0.4$

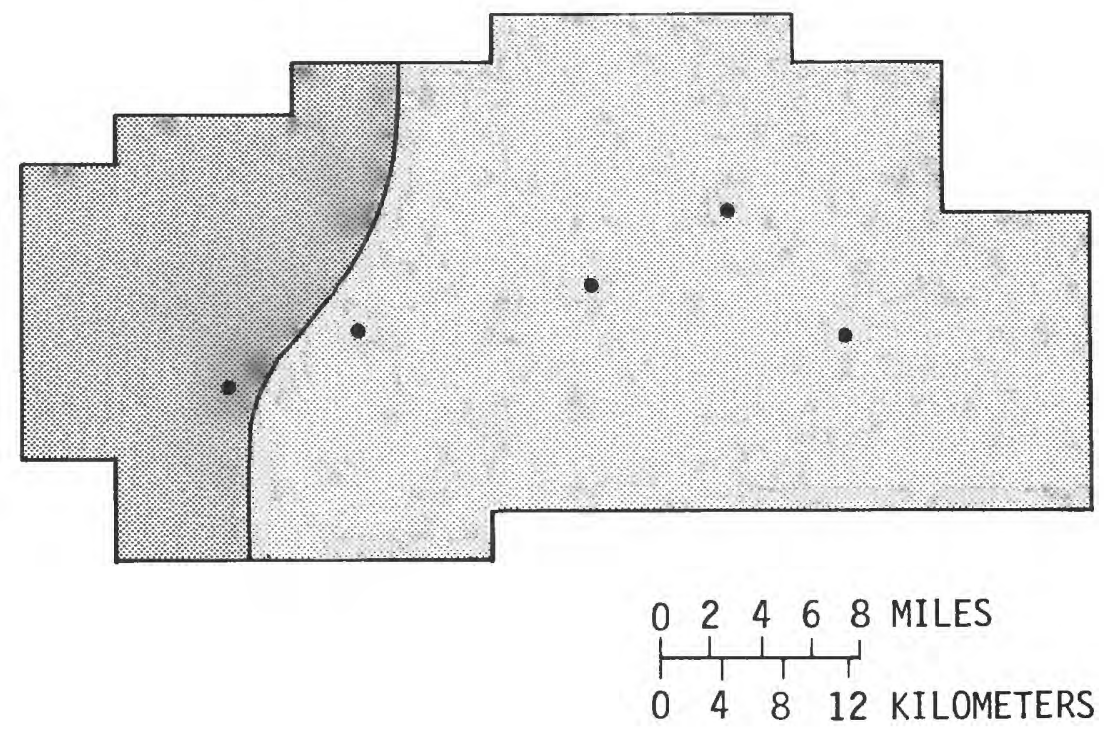

FIGURE 7.--Calibrated leakance $(\mathrm{K} / \mathrm{m})$ distribution for confining layers between adjacent units. 


\section{Vertical Recharge from Land Surface}

The aquifer system in Toppenish Creek basin is recharged as a result of the infiltration of precipitation and applied irrigation water. The

distribution in time and space of vertical recharge depends primarily on the distribution in time and space of precipitation, irrigation, evapotranspiration (ET), and runoff. Any residual water as a result of the combination of these processes is assumed to infiltrate the aquifer system.

Because the water levels of unit 1 are held constant in this analysis, vertical recharge is calculated for unit 2 only in those areas where unit 2 is exposed at the surface, or unit 1 thickness is insignificant. In addition, the vertical recharge is assumed constant with time, because the data are insufficient to delineate a temporal distribution, and time-varying recharge estimates are not needed for this model.

Calculation of vertical recharge from land surface to unit 2 was made using the following equation:

$$
\text { RECH = PRECIP + IRR - ET - RUNOFF }
$$

where RECH = vertical recharge to unit 2 from land surface,

PRECIP = precipitation,

IRR = irrigation,

ET = evapotranspiration, and

RUNOFF = runOff.

Not all elements in equation 4 could be properly defined with data from the Toppenish Creek basin alone. However, the basin is topographically, climatologically, and agriculturally similar to the Walla Walla basin approximately 100 miles east. Owing to the similarities, and because the terms in equation 4 have been more accurately determined for the Walla Walla basin, some relations found to exist in that basin were used to calculate vertical recharge for the Toppenish Creek basin.

Recently published data, based on precipitation records from 1931 to 1965 plus snow surveys from 1964 to 1974 (Central Washington State College, 1976), were used on the present model study. The precipitation data given for the Toppenish Creek basin in U.S. Geological Survey (1975) were initially incorporated in the model. However, these data, based on shorter length records, were not compatible with the other factors in the above equation.

Vertical recharge from infiltration of irrigation waters was calculated for those areas below the Highline Canal (fig. 1) where unit 2 is at land surface. As suggested by Barker and Mac Nish (1976, p. 20) for the Walla Walla basin, the annual rate of application was assumed to be 4.5 feet of water. 
Discharge from unit 2 via evapotranspiration was computed in two different ways, depending on whether or not an area was irrigated. For irrigated areas, ET was assumed to be 64 percent of the sum of precipitation and irrigation, based on the overall relations between these processes in the Wa1la Wa1la basin (Barker and Mac Nish, 1976, table 1). For the non-irrigated areas of the mountains and foothills, ET was computed as a function of precipitation (Hulet, 1969, p. 4), in which the soll was assumed to hold moisture to a depth of 6 inches. ET was assumed to equal precipitation in those areas where the latter was less than 11 inches per year.

Runoff for the mountainous areas of the basin was determined from the long-term average rates of discharge of Toppenish Creek and Simcoe Creek, as measured at U.S. Geological Survey gaging stations near Ft. Simcoe and below Spring Creek near Ft. Simcoe, respectively (fig. 1). Runoff for the lowland areas of the basin was assumed to be 25 percent of the sum of precipitation and irrigation. This simplification was based on the findings in the Walla Walla basin (Barker and Mac Nish, 1976, table 1) and was made necessary by the complicated interactions among runoff, canal flow, and irrigation diversions which prevail in the lowland area of the Toppenish Creek basin.

After equation 4 was used for calculating vertical recharge from land surface to appropriate nodes of unit 2, a mathematical-averaging procedure was used to distribute these values more evenly among the nodes. The total amount of calculated vertical recharge from land surface to unit 2 remained the same during this adjustment, but the procedure was necessary to provide a pattern of recharge for better calibration.

The final calibrated vertical recharge rate from land surface to unit 2 (fig. 8) ranges from zero up to $17.5 \times 10^{-9}$ feet per second and recharge totals 28,900 acre-feet per year. This major recharge to unit 2 is approximately seven times greater than the lateral inflow to units 2 and 3 under steady-state (1954) conditions (see table 2). Although many generalizations and assumptions are inherent in these rates, they represent the long-term averages of the area and, thus, should be adequate for the present model.

\section{Pumpage}

The major pumping in the Toppenish Creek basin is from unit 3 , the primary basalt aquifer, and is principally for irrigation of lands west of and higher than the Highline Canal (fig. 1). Before 1955, the annual pumpage from unit 3 was less than 500 acre-feet, but increased from 1,500 acre-feet in 1955 to an annual rate of about 15,000 acre-feet from 1968 through 1972 (U.S.

Geological Survey, 1975, fig. 26). This pumpage has resulted in head declines of 70 feet or more in unit 3 during the period 1960 to 1970 (U.S. Geological Survey, 1975, fig. 5). Pumpage from unit 3 , as well as from unit 2, has caused some decline in unit 2 also. In 1972, annual pumpage from unit 2 included about 3,700 acre-feet for municipal use in the towns of Wapato and Toppenish, and about 800 acre-feet for irrigation.

Pumping of water for domestic purposes is small in comparison to that for irrigation and municipal needs. Consequently, that pumpage has not been included in this study. 


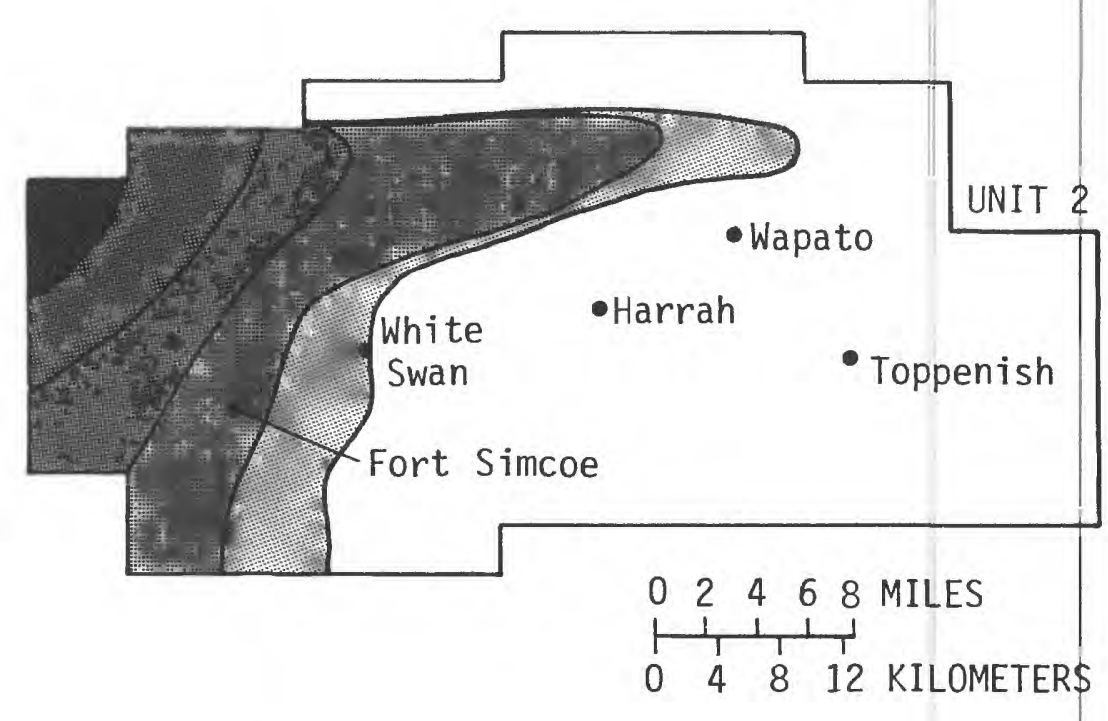

EXPLANATION

Vertical-recharge rate, in feet per second $\times 10^{-9}$

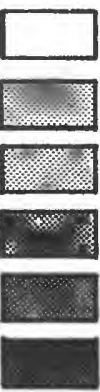

0

$1.5-2.5$

$2.5-5.0$

$5.0-10.0$

$10.0-15.0$

$15.0-17.5$

FIGURE 8.--Calibrated vertical-recharge-rate distribution from land surface to unit 2.

TABLE 2.--Water budget for units 2, 3, and 4 for steady-state (1954) conditions

\begin{tabular}{|c|c|c|c|}
\hline \multirow[b]{2}{*}{ Item } & \multicolumn{3}{|c|}{ (acre-feet per year) } \\
\hline & Unit 2 & Unit 3 & Unit 4 \\
\hline \multicolumn{4}{|l|}{ Inflow } \\
\hline Vertical recharge & 28,900 & $\ldots . .$. & .... \\
\hline Lateral underflow & 2,800 & 1,600 & $\ldots$. \\
\hline Leakage from overlying unit & $\ldots . .$. & 10,400 & 4,000 \\
\hline TOTAL & $\overline{31,700}$ & $\overline{12,000}$ & $\overline{4,000}$ \\
\hline \multicolumn{4}{|l|}{ Outflow } \\
\hline Latera1 underflow & 10,000 & 8,000 & 4,000 \\
\hline Leakage to overlying unit & 11,300 & $\ldots .$. & $\ldots .$. \\
\hline Leakage to underlying unit & 10,400 & 4,000 & $\cdots$ \\
\hline TOTAL & $\overline{31,700}$ & $\overline{12,000}$ & $\overline{4,000}$ \\
\hline Change in storage & 0 & 0 & 0 \\
\hline
\end{tabular}


The latest pumping rates used in the model were taken as the average annual rate for 1971 and 1972, about 4,500 acre-feet from unit 2 and 15,100 acre-feet from unit 3 . This pumpage distribution is given in figure 9 . Estimates of these rates were obtained from power-consumption records. (See Luzier and Burt, 1974, for the method of calculation.)

Annual irrigation pumpages from 1955 through 1970 have been calculated for the use in the model by using the 1971 to 1972 average annual pumpage from unit 3 and the annual basalt pumpages from 1955 to 1970 (U.S. Geological Survey, 1975, fig. 26). This technique, which was necessary because of lack of data to define yearly pumping distributions, scales each 1971-to-1972 average annual irrigation-pumping-node rate by the ratio of total basalt pumpage in any year from 1955 to 1970 (U.S. Geological Survey, 1975, fig. 26) to 15,100 acre-feet to get the nodal rate in a particular year. For example, since 1,360 acre-feet were pumped from the basalt in 1955 (or 9 percent of the 1971 to 1972 average), 9 percent was the factor to scale individual irrigation-pumping nodes for 1955. The municipal pumping-node rates, totalling 3,700 acre-feet per year for 1971 and 1972 , were not affected by this factor. However, 1955 municipal rates were reduced to 75 percent of 1971-to-1972 rates, with smaller reductions in the ensuing years.

One simplification used in the model was to have uniform pumping rates for the entire year, with rates changing yearly from 1955 to 1972, instead of an on-and-off pumping season. This simplification is in accord with removing the temporal distribution of vertical recharge from land surface to unit 2 , which was discussed previously.

\section{Calibration}

Calibration of a ground-water flow model is the trial-and-error process of adjusting initial estimates of aquifer parameters to obtain a better match of measured and calculated heads. The parameter adjustments are kept within reasonable limits, based on rational hydrologic and geologic reasoning. The closeness of the resulting match is affected by the complexity of the real system, the accuracy of the input data, and time and budgetary constraints on the study.

In order to better understand the aquifer system and to hasten the calibration process, the present study included both an iterative steady-state analysis and a transient-state analysis. In general, transmissivities and leakance terms were varied in the steady-state phase of calibration. These parameters and resulting steady-state heads were then used in the transientstate phase. Storage coefficients were varied in the transient-state phase to obtain a reasonable match of historic and computed water levels. Often, changes in storage coefficients were not sufficient for this transient-state match. In such cases, the calibration procedure required repeating the steady-state analysis and then the transient analysis to obtain the desired match of measured and computed heads. 


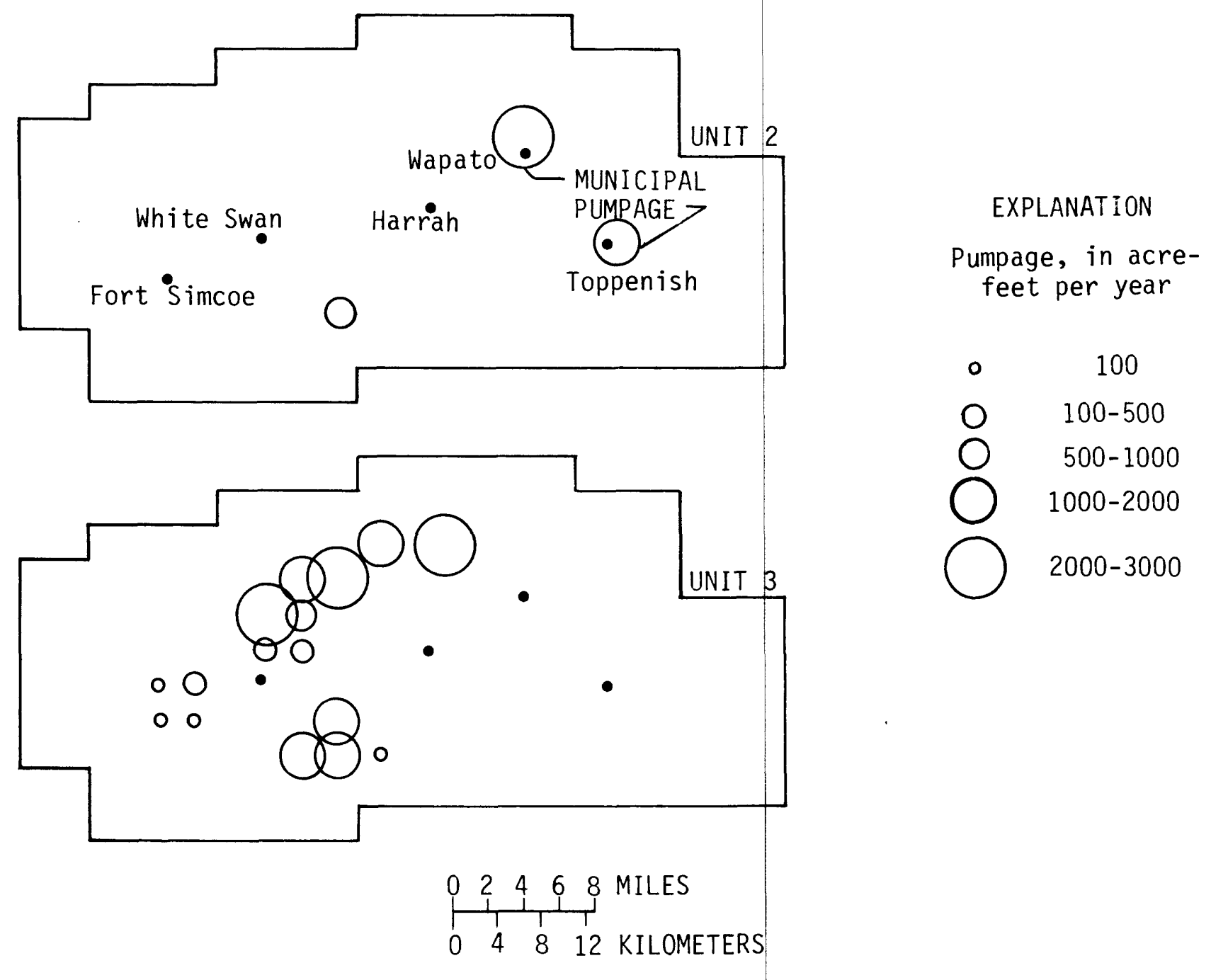

FIGURE 9.--Average annual pumpage distribution, 1971-72. 
A steady-state condition of an aquifer system is one in which heads do not change with time. Such a state is rarely found in nature because of dynamic changes in hydrologic factors which directly affect heads. For example, precipitation recharging an aquifer is uniform in neither space nor time. However, if heads are cyclical, returning to nearly the same level each year, then the aquifer approximates a steady-state condition. As previously discussed, unit 1 exhibits such cyclic fluctuations.

No water-level data are avallable before 1955, when significant pumping began from unit 3. However, there is indirect evidence of water-1evel rises due to irrigation with imported water, which began in the early 1900's (U.S. Geological Survey, 1975, p. 40). Consequently, it is assumed that before 1955, water levels in units 2,3 , and 4 also were cyclic, reaching approximately the same level each year. Thus, the calibration period for the steady-state analysis was chosen as 1954, when levels in all units were assumed cyclical, and before the beginning of significant pumping from unit 3 .

There are no storage-coefficient terms in equation 2 for steady-state conditions because there is no change in head with time, or, equivalently,

$$
\frac{\delta h_{i}}{\delta t}=0 \text { for } i=2,3 \text {, and } 4 \text {. }
$$

Thus, the only aquifer parameters that needed to be adjusted to calibrate the model to steady-state conditions were transmissivity and leakance.

The 1954 potentiometric surface as a result of steady-state calibration is shown in figure 10. Because there are no water-level measurements available prior to 1955, hydrographs in figure 26 of U.S. Geological Survey (1975) were extrapolated back to 1954 and then used in a generalized fashion in the steady-state calibration.

The water budget as a result of the steady-state analysis for 1954 was used both for calibration and as a check on the validity of the model. For a proper steady-state solution, inflow must equal outflow for each unit. The magnitudes and signs of the budget items for each unit were also used, in conjunction with a conceptual model of the aquifer system as supported by previous studies. (For example, see fig. 32, U.S. Geological Survey, 1975.)

Table 2 gives the water budget for units 2, 3, and 4, based on the 1954 head distribution as a result of steady-state calibration. Because unit 1 is not included, the budget for the entire aquifer system is not shown.

Disregarding unit 1 , inflow is primarily from vertical recharge to unit 2, with some lateral underflow into units 2 and 3 from adjacent areas in the west and north. Outflow is by lateral underflow to the east from all three units. 

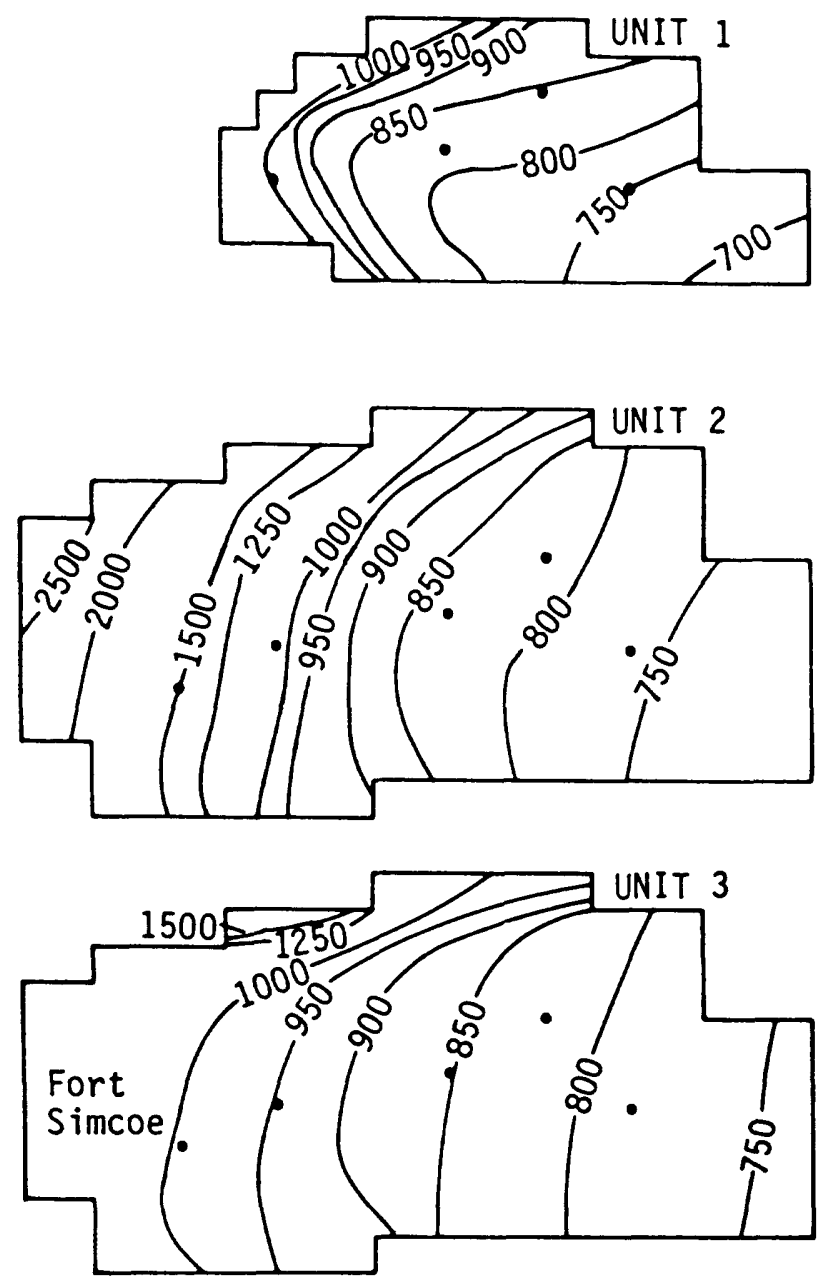

\section{EXPLANATION}

- 800 - POTENTIOMETRIC CONTOUR--shows altitude at which water level would have stood in tightly cased wells. Contour interval is variable. Datum is sea level.

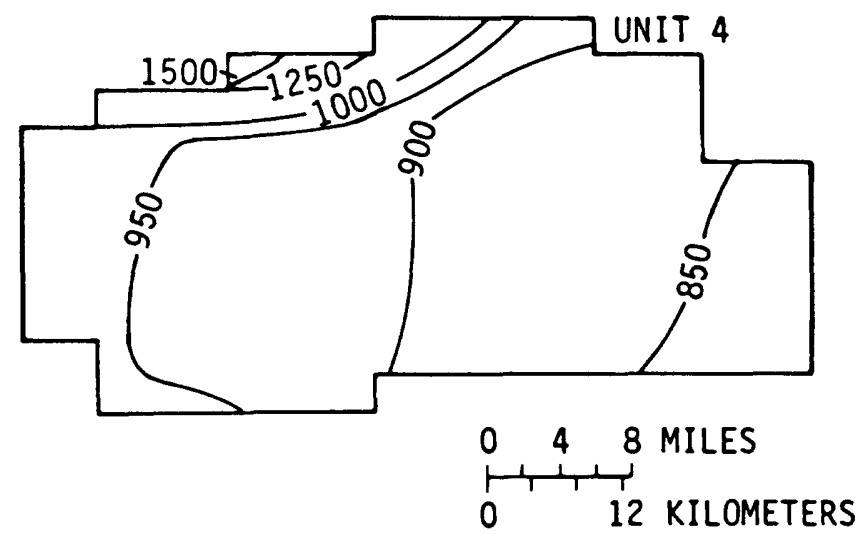

FIGURE 10.--Heads in 1954 as a result of steady-state calibration of units 2,3 , and 4 . 
The transient state of an aquifer is a condition of changing heads with time. In this case, storage coefficients are present in equation 2 for each unit and are the primary aquifer parameters varied during calibration. The period of calibration was January 1955 through December 1972; 1972 was chosen as the ending year because that was the most recent year that water levels were collected over the entire basin.

The primary historical data used in the transient-state calibration were the head declines in unit 3 from 1960 to 1970 (U.S. Geological Survey, 1975, fig. 25). In addition, five hydrographs of water-level measurements in units 2 and 3 were used for matching computed hydrographs during the callbration.

The transient-state analysis used the heads simulated in the steady-state analysis (fig. 10) as the initial heads in 1955. Then the model was run for the transient-state calibration period, using estimates of the historical pumpage. The December 1972 heads as a result of the transient-state calibration process are shown in figure 11.

A comparison of measured and calculated 1960-to-1970 declines in unit 3 was one check of the model calibration. As shown in figure 12, the patterns and magnitudes of measured and computed declines are similar. However, the maximum calculated declines of about 60 feet were 10 to 15 feet less than the corresponding measured declines. This discrepancy may be partly explained by the fact that the computed head is for the entire element and, as such, would underestimate the localized effect of a small pumping depression. (For example, see Luzier and Skrivan, 1975, p. 27.) In areal comparison, the calculated 1960-to-1970 declines in unit 3 have a broader extent than indicated by the measured declines. This discrepancy is due partly to insufficient data to define more accurate contours in figure $25, \mathrm{U} . \mathrm{S}$. Geological Survey (1975). In addition, those comparisons are affected by the accuracy of pumping rates and distributions of $T, S$, and leakage.

Comparisons of measured and computed drawdowns for the transient-state calibration are given in figures 13 through 15 . Nodes nearest the particular wells were those selected for comparison; the locations of these nodes are shown in figure 11. As stated on pages 27 and 28 of Luzier and Skrivan (1975), computed pumping levels cannot accurately duplicate measured pumping levels, but recovery levels after a pumping season should match computed levels.

The calculated water budget for 1972 is given in table 3 . A comparison of tables 2 and 3 points out the effects of pumping from units 2 and 3 . This pumpage has increased downward leakage from unit 1 to unit 2 , and from unit 2 to unit 3 , the leakages during 1972 being 4,700 acre-feet and 23,750 acrefeet, respectively. The pumping stress has also caused depletion of ground water in storage: 1,850 acre-feet in unit $2 ; 1,400$ acre-feet in unit 3 ; and 350 acre-feet in unit 4 in 1972 . 

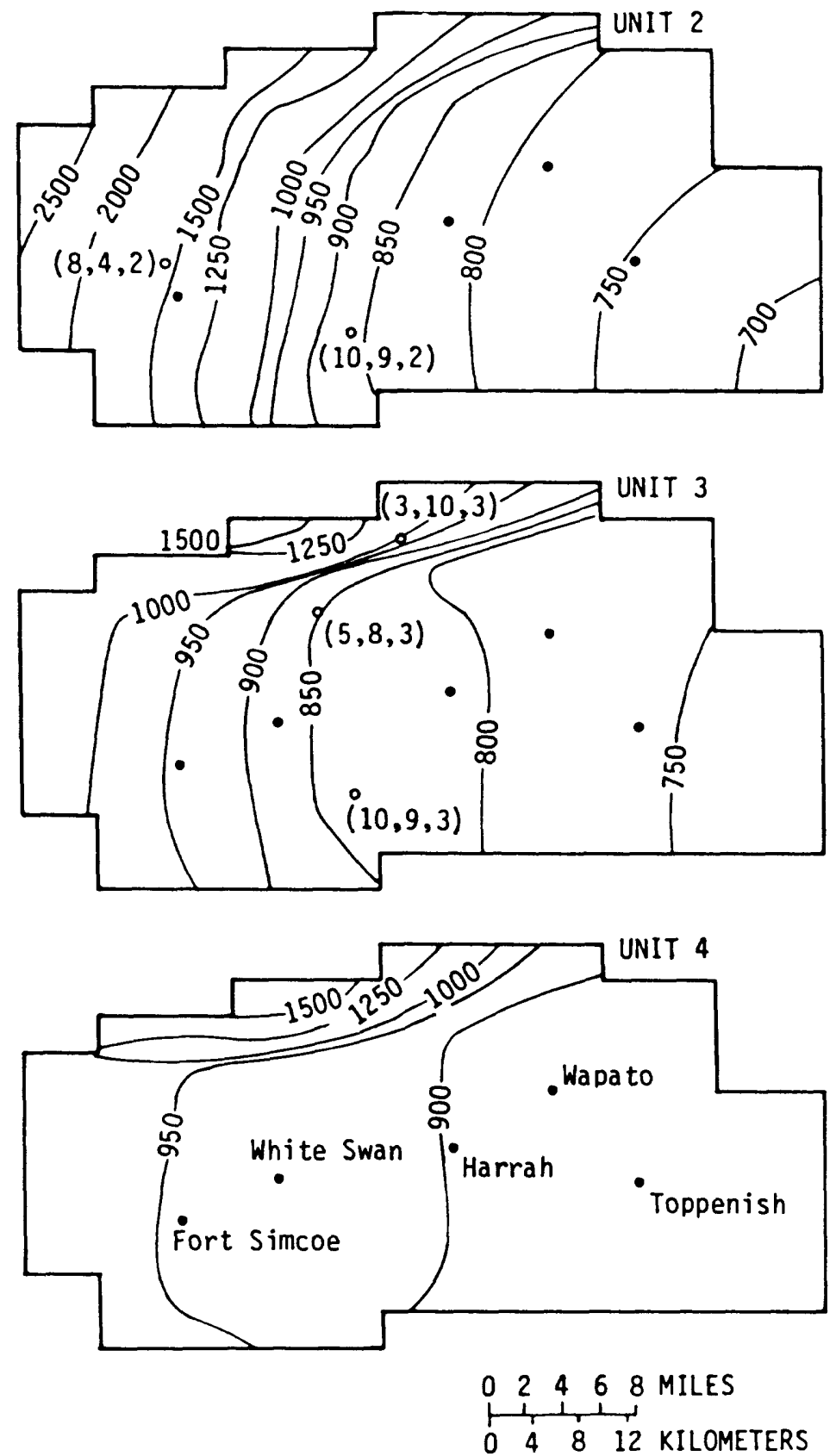

\section{EXPLANATION}

750 - POTENTIOMETRIC CONTOUR-shows al titude at which water level would have stood in tightly cased wells. Contour interval is variable. Datum is sea level.

$\bullet(\$, 4,2) \quad$ Node number

FIGURE 11.--Head in December 1972 as a result of transient-state calibration of units 2,3 , and 4 . 


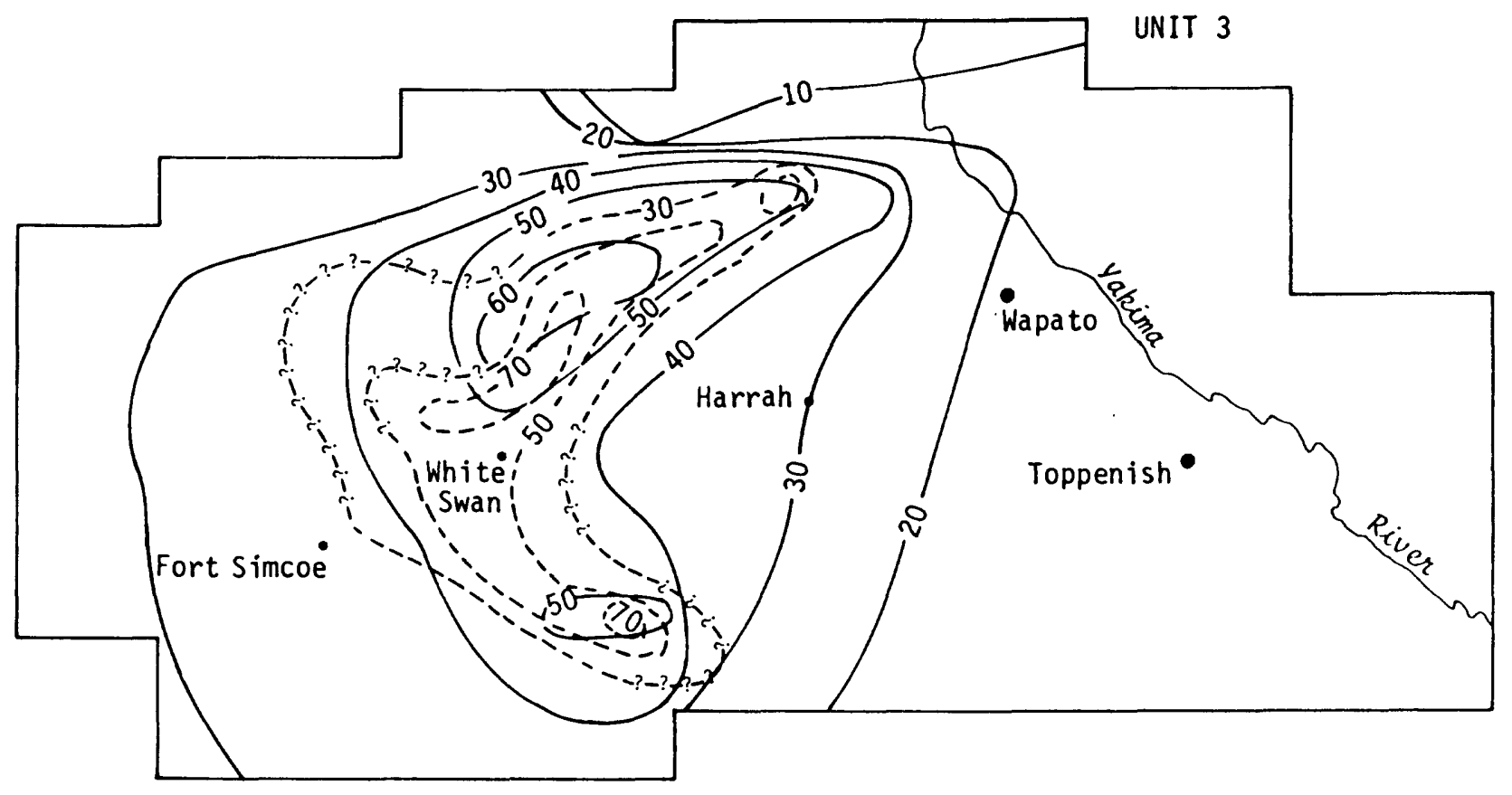

EXPLANATION

$-10--\begin{aligned} & \text { Line of measured equal head } \\ & \text { decline, queried where ap- } \\ & \text { proximately located }\end{aligned}$
in feet

FIGURE 12.--Comparison of measured and calculated 1960-70 head decline in unit 3. 


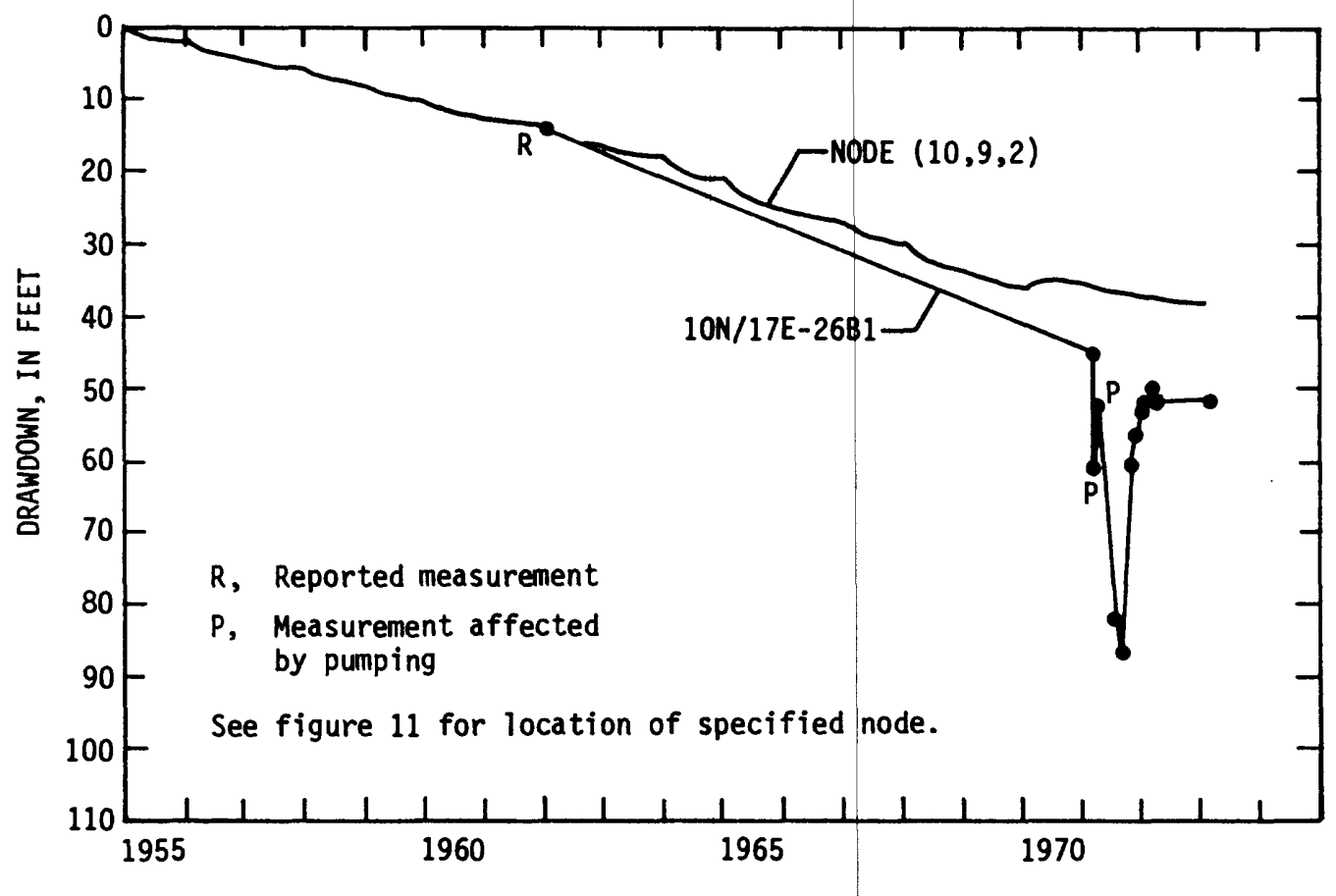

FIGURE 13.--Comparison of measured and computed drawdown at node $(10,9,2)$.

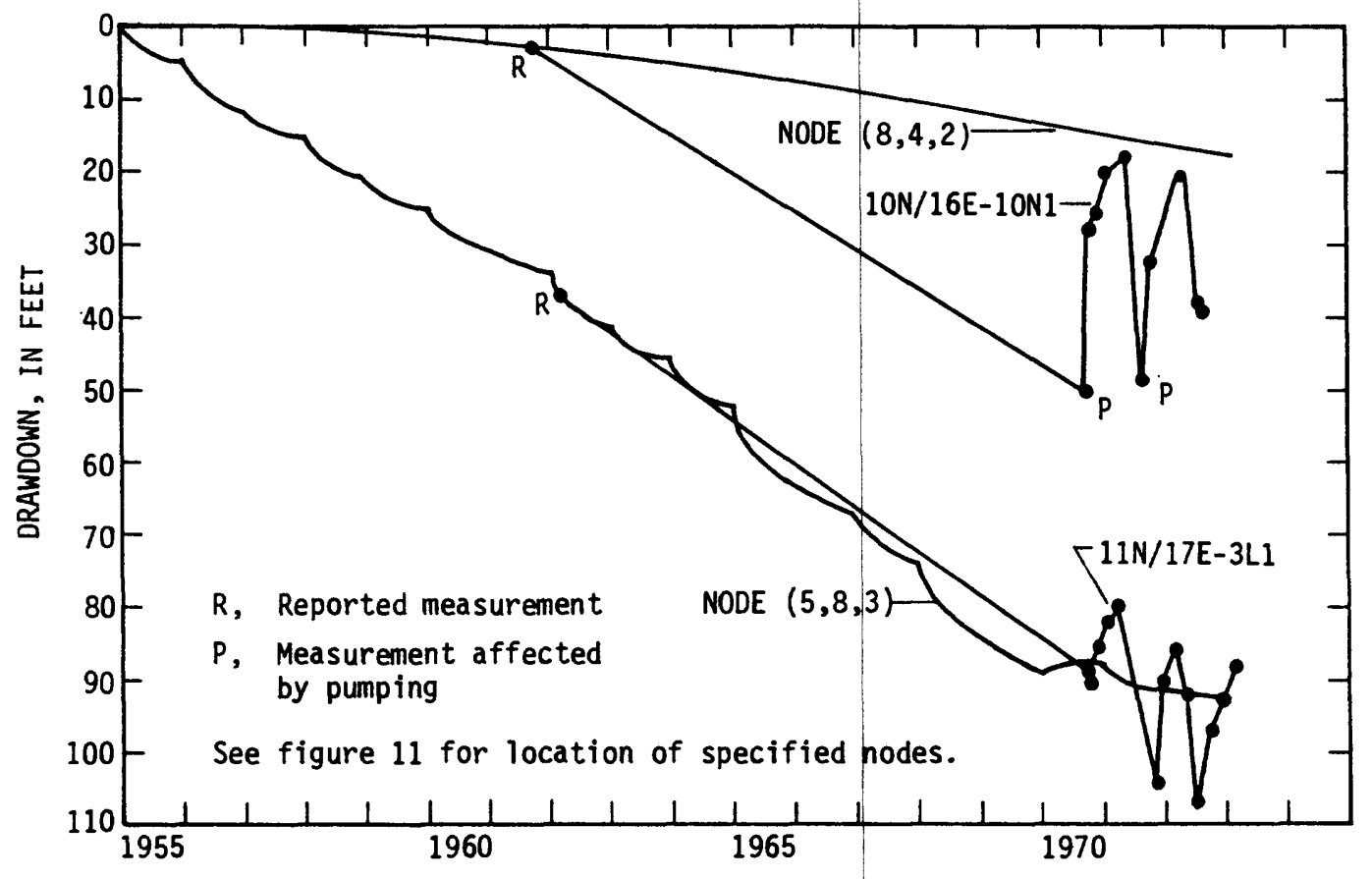

FIGURE 14.--Comparison of measured and computed drawdown at nodes $(8,4,2)$ and $(5,8,3)$. 


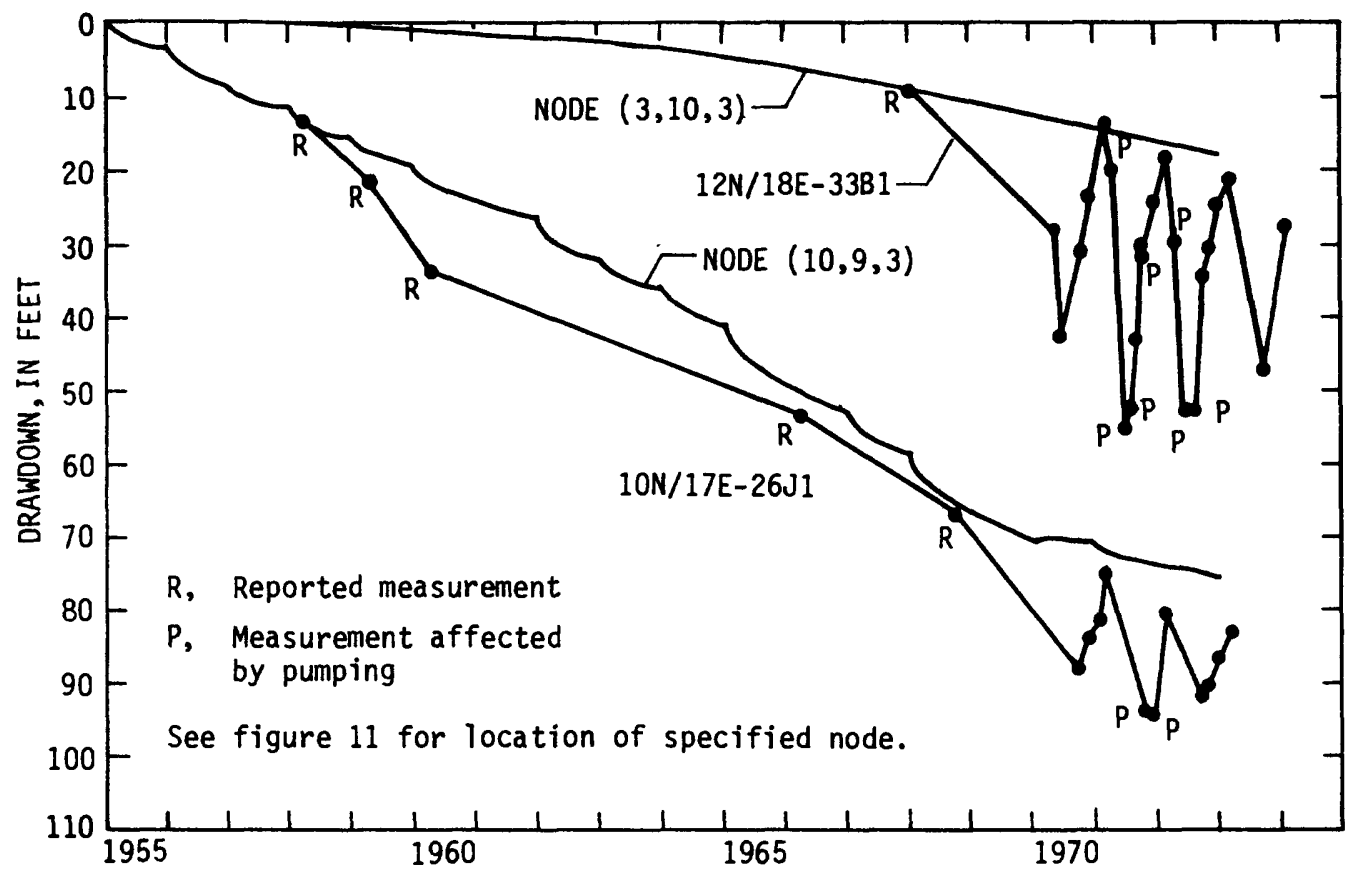

FIGURE 15.--Comparison of measured and computed drawdown at nodes $(3,10,3)$ and $(10,9,3)$.

TABLE 3.--Water budget for units 2, 3, and 4 for 1972

\begin{tabular}{|c|c|c|c|}
\hline \multirow[b]{2}{*}{ Item } & \multicolumn{3}{|c|}{ (acre-feet per year) } \\
\hline & Unit 2 & Unit 3 & Unit 4 \\
\hline \multicolumn{4}{|l|}{ Inflow } \\
\hline Vertical recharge & 28,900 & $-\ldots$ & $-\ldots$ \\
\hline Lateral underflow & 2,800 & 1,600 & $-\ldots$ \\
\hline Leakage from overlying unit & 4,700 & 23,750 & 3,650 \\
\hline TOTAL & $\overline{36,400}$ & $\overline{25,350}$ & $\overline{3,650}$ \\
\hline \multicolumn{4}{|l|}{ Outflow } \\
\hline Lateral underflow & 10,000 & 8,000 & 4,000 \\
\hline Leakage to underlying unit & 23,750 & 3,650 & $-\ldots$ \\
\hline Pumpage & 4,500 & 15,100 & $-\cdots$ \\
\hline TOTAL & $\overline{38,250}$ & $\overline{26,750}$ & $\overline{4,000}$ \\
\hline Change in storage & $-1,850$ & $-1,400$ & -350 \\
\hline
\end{tabular}


The effect of pumpage from 1955 to 1972 is also reflected in the calculated annual vertical leakage between units (fig. 16). The general increase in pumpage, mainly from unit 3 , corresponds to an increase in downward leakage from units 1 to 2 and from units 2 to 3 because of larger head differences between units 1 and 2 and units 2 and 3 . On the other hand, vertical leakage from units 3 to 4 has gradually decreased because of smaller head differences between units 3 and 4 .

Leakage from unit 1 to unit 2 over the transient period represents captured water in comparison to the steady-state period where vertical leakage from unit 2 to unit 1 was 11,300 acre-feet per year (table 2). As shown in figure 16, this leakage upward had decreased from 1955 through 1966 and, in fact, reverses direction, going from unit 1 to unit 2 from 1967 through 1972.

The depletion of ground water in storage during the transient period (fig. 17) is also a result of pumpage. However, in general the magnitudes of annual depletion are smaller than those of annual vertical leakage. Figure 17 indicates a higher annual depletion in unit 3 than unit 2 from 1955 through 1969. However, a reduction in pumpage from 1970 through 1972 (fig. 26, U.S. Geological Survey, 1975) caused a much greater reduction in annual depletion in unit 3 as compared with units 2 and 4 . Consequently, the calculated annual depletion of ground-water storage from 1970 through 1972 was greater in unit 2 than in unit 3 . 


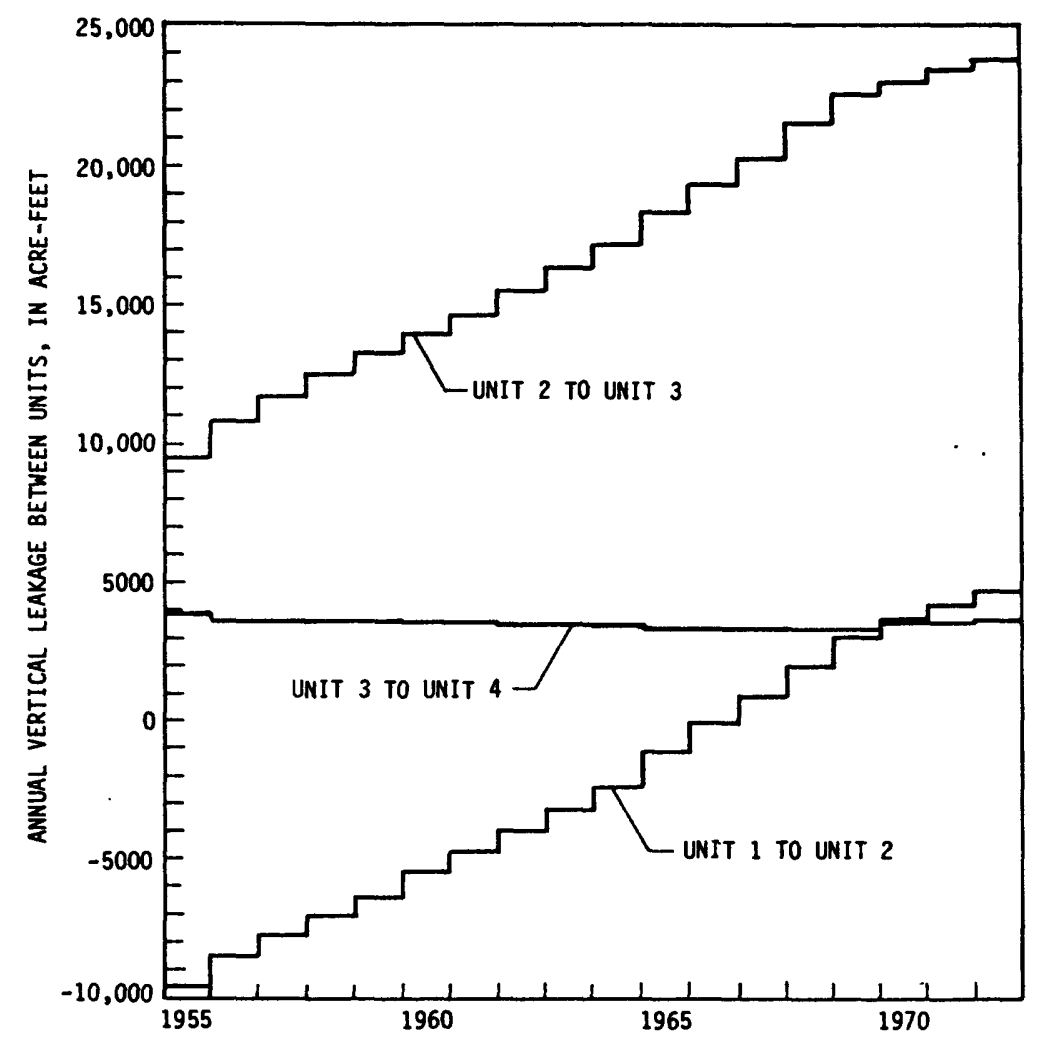

FIGURE 16.--Calculated annual vertical leakage between units.

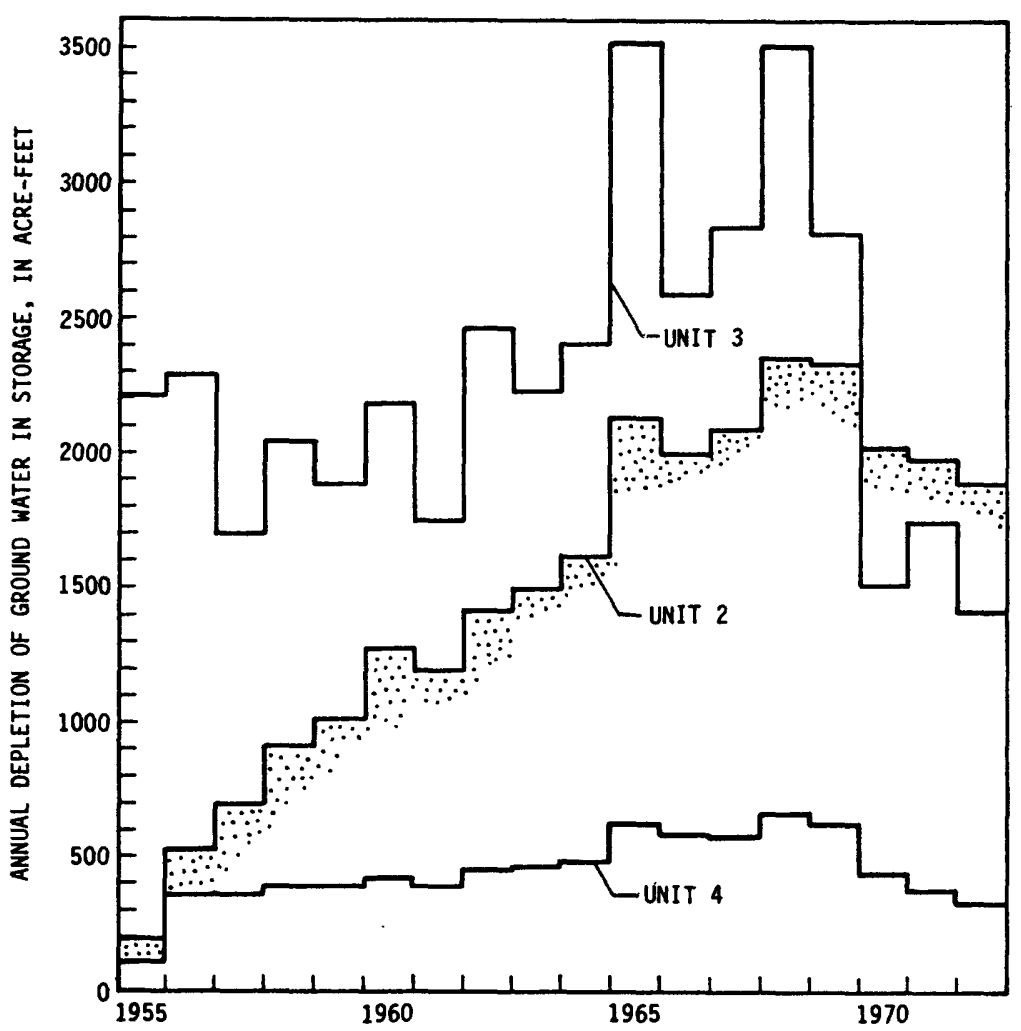

FIGURE 17.--Calculated annual depletion of ground water in storage in units 2 , 3 , and 4 . 
An important use of the calibrated model of the Toppenish Creek basin aquifer system is to predict future water levels as a result of existing or proposed pumping patterns. Potential ground-water development in nonirrigated areas can be evaluated, for example. Such predictions can be assumed to be reasonably reliable if present hydrologic conditions persist into the future.

Two projections of head declines from 1973 through 1982 were made, using the aquifer parameters obtained from the calibration process and the computed December 1972 potentiometric surface as initial conditions. The first projection used 1971-to-1972 average annual pumpage, about 19,600 acre-feet, and the second projection increased that pumpage by 12,400 acre-feet per year beginning in 1978 .

\section{Projection with 1971-to-1972 Average Annual Pumpage}

The projection of heads from 1973 through 1982, using 1971-to-1972 average annual pumpage, assumes no increase in pumpage from the period 1971to-1972 to the present (1978) and no predicted increase through 1982. There are indications that the first assumption is valid ( $\mathrm{J}$. Allsop, oral commun., 1977). The 1971-to-1972 average annual pumpage consists of the amounts shown in table 3; about 4,500 acre-feet from unit 2 and 15, 100 acre-feet from unit 3 .

The projected head declines from January 1973 through December 1977 and from January 1978 through December 1982 are given in figures 18 and 19 , respectively. The calculated average annual rate of decline in the middle part of the basin from 1973 through 1977 is about 0.1 to 1.0 foot from unit 2 and 0.2 to 1.5 feet from unit 3 . The corresponding values from 1978 through 1982 are 0.1 to 1.2 feet from unit 2 and 0.2 to 0.8 foot from unit 3 in the central part of the basin. The calculated water budget for units 2,3 , and 4 for 1982 (table 4) shows smaller change-in-storage rates compared to the corresponding rates in 1972 (table 3). However, the calculated leakage downward from unit 1 to unit 2 in 1982 is greatef than that calculated for 1972 .

Hydrographs of project drawdown from 1973 through 1982 of selected nodes using the 1971-to-1972 average annual pumpage are given in figure 20. These hydrographs reflect a reduced rate of decline in the later years compared to the earlier years. 
EXPLANATION

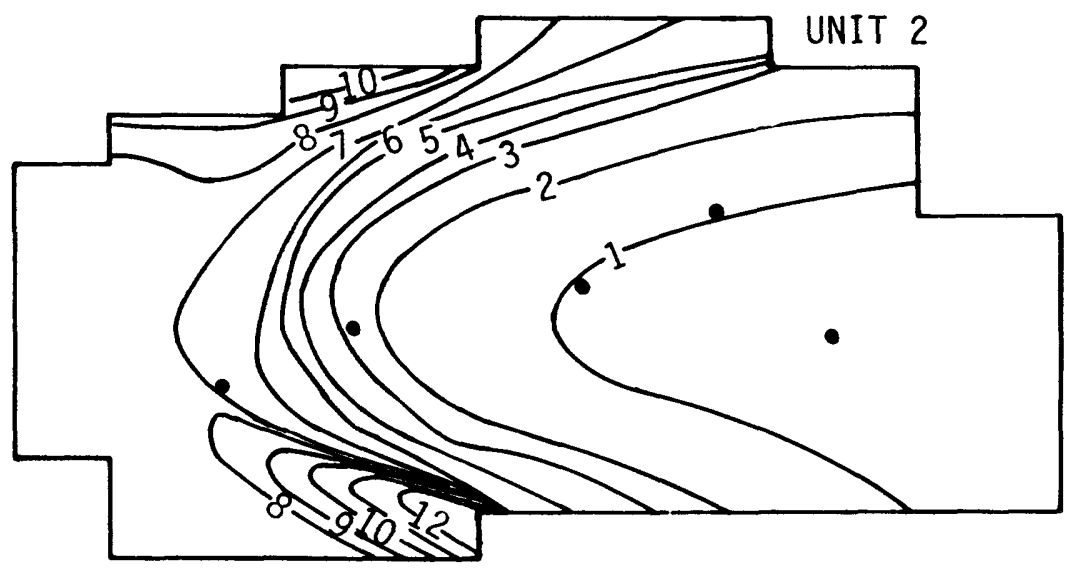

- $11-$

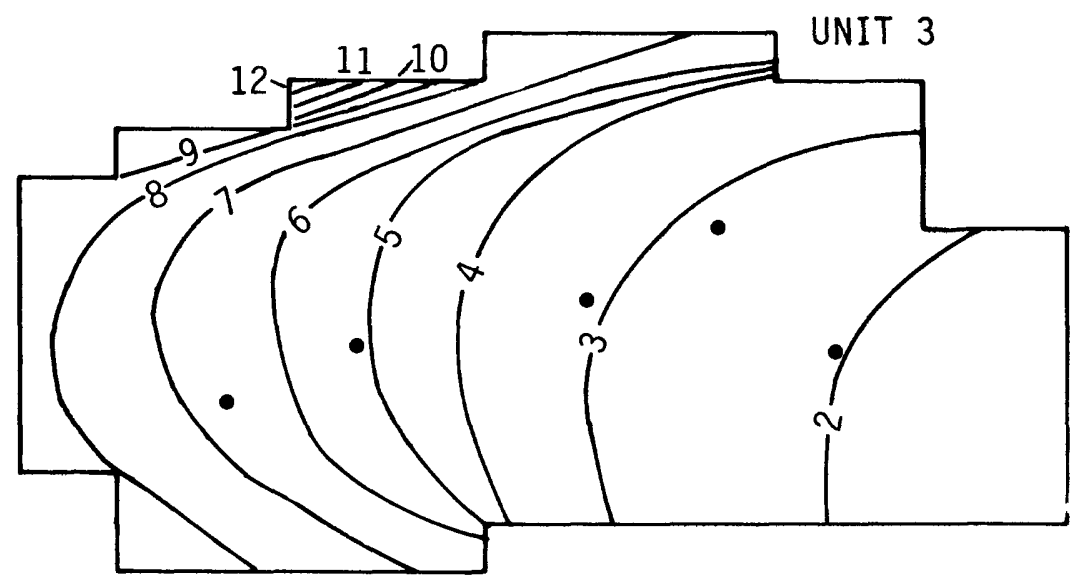

Line of equal head decline. Interval 1 foot

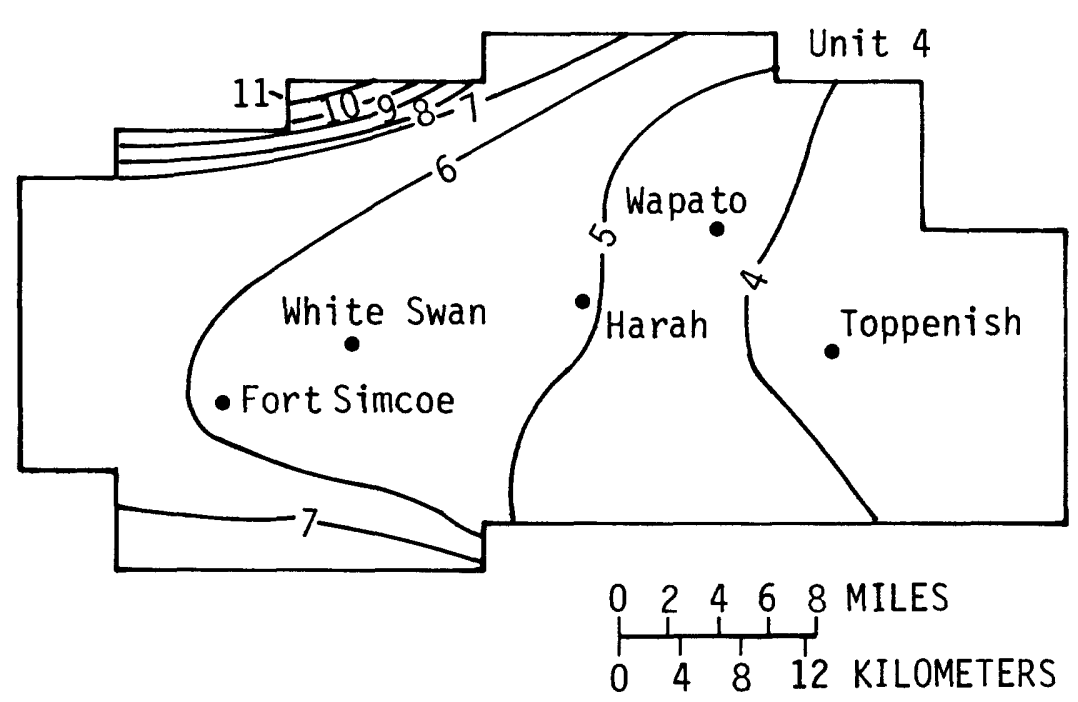

FIGURE 18.--Projected head decline from 1973 through 1977 in units 2, 3, and 4, using 1971-72 average annual pumpage. 

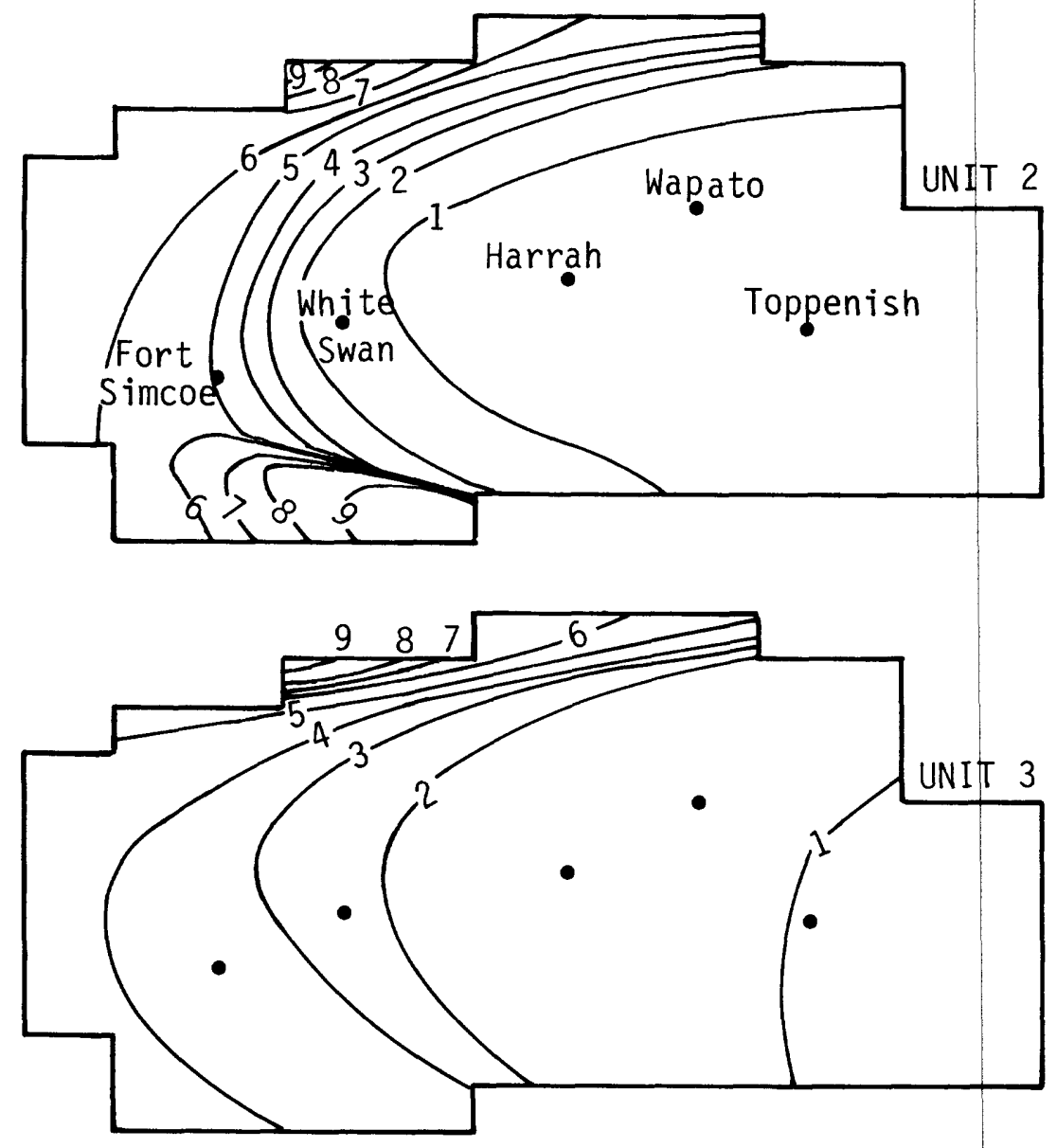

\section{EXPLANATION}

Line of equal head decline--interval 1 foot

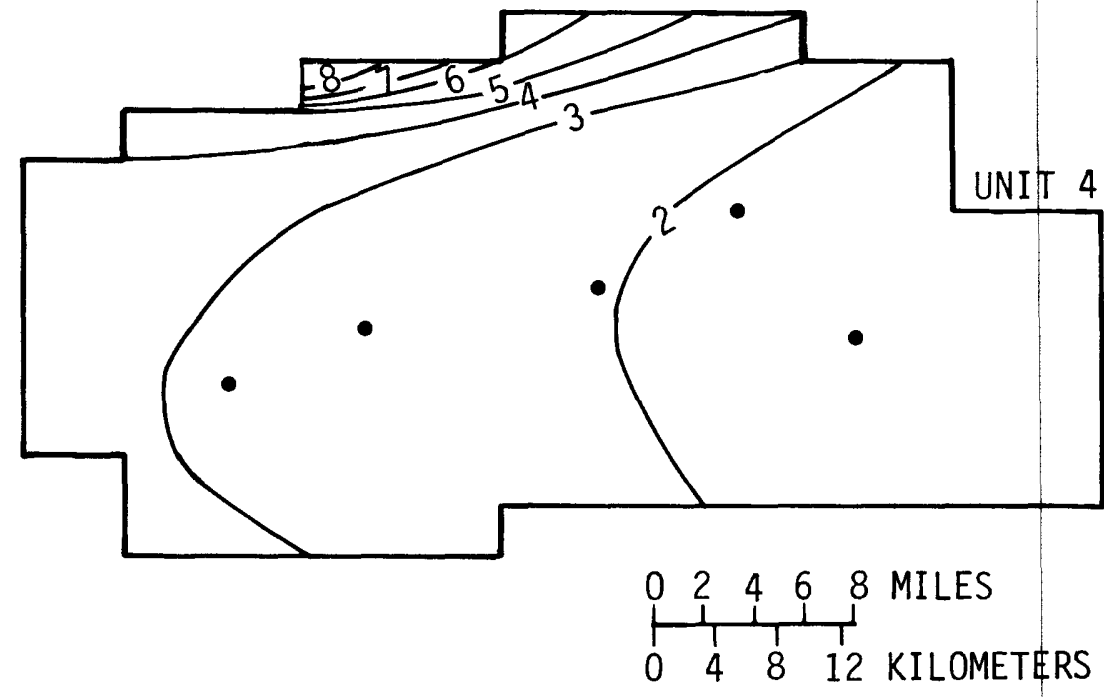

FIGURE 19.--Projected head decline from 1978 through 1982 in units 2, 3, and 4, using 1971-72 average annual pumpage. 
TABLE 4.--Projected water budget for units 2, 3, and 4 for 1982 , using 1971 to 1972 average annual pumpage

\begin{tabular}{|c|c|c|c|}
\hline \multirow[b]{2}{*}{ Item } & \multicolumn{3}{|c|}{ (acre-feet per year) } \\
\hline & Unit 2 & Unit 3 & Unit 4 \\
\hline \multicolumn{4}{|l|}{ Inflow } \\
\hline Vertical recharge & 28,900 & $-\ldots$ & -... \\
\hline Lateral underflow & 2,800 & 1,600 & $\ldots$ \\
\hline Leakage from overlying unit & 6,750 & 25,050 & 3,900 \\
\hline TOTAL & $\overline{38,450}$ & $\overline{26,650}$ & $\overline{3,900}$ \\
\hline \multicolumn{4}{|l|}{ Outflow } \\
\hline Lateral underflow & 10,000 & 8,000 & 4,000 \\
\hline Leakage to underlying unit & 25,050 & 3,900 & $\ldots$. \\
\hline Pumpage & 4,500 & 15,100 & $\ldots$ \\
\hline TOTAL & $\overline{39,550}$ & $\overline{27,000}$ & $\overline{4,000}$ \\
\hline Change in storage & $-1,100$ & -350 & -100 \\
\hline
\end{tabular}

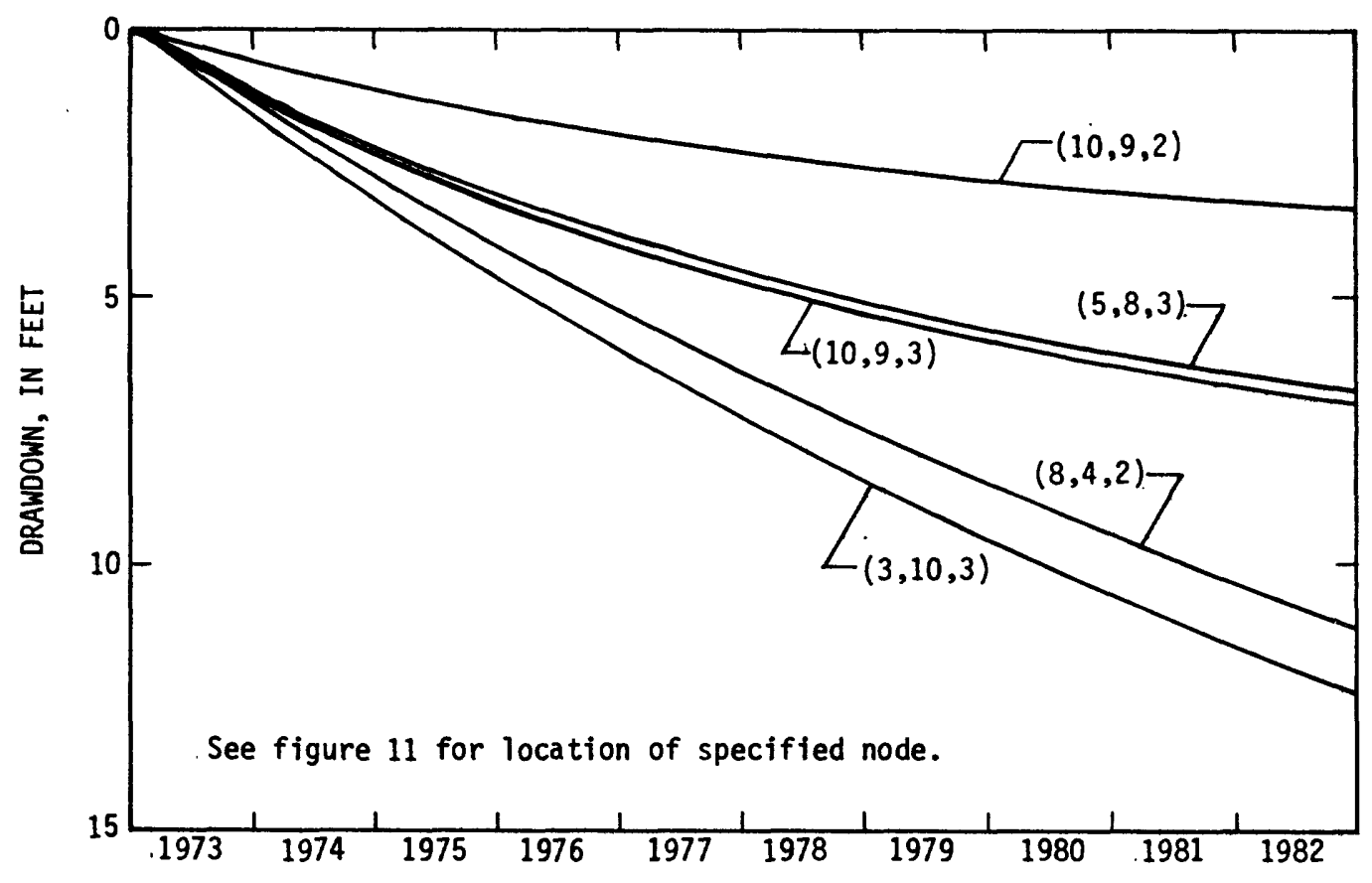

FIGURE 20.--Projected drawdown from 1973 through 1982 at selected nodes, using 1971-72 average annual pumpage. 
Another static-head projection was made using annual pumpage of 1971-to1972 plus 12,400 acre-feet of new annual pumpage from unit 3 for the period January 1978 through December 1982. The increase in pumpage in unit 3 is about 80 percent, thus representing significant additional stress. The areal distribution of pumping chosen for 1978 to 1982 is shown in figure 21. The areas of additional pumping can be determined by comparing figure 21 with figure 9, the distribution of 1971-to-1972 average annual pumpage.

The decline in unit 3 from 1978 through 1982 (fig. 22) caused by the combined annual pumpage of about 27,500 acre-feet from unit 3 and 4,500 acrefeet from unit 2 is over 100 feet in and near the area of new pumping. The calculated annual rate of decline in units 2 and 3 from 1978 through 1982 is about 1 to 6 feet and 4 to 20 feet, respectively. Figure 23 shows the hydrographs from 1978 through 1982 at selected nodes. The accelerated declines starting in January 1978 , especially at nocie $(10,9,3)$, are readily apparent.

The results of a projection based on increasing pumpage in unit 3 by 80 percent should be treated only as a general guide in evaluating the hydrologic effects, because such an increase could well change the recharge-discharge relation under which the model was calibrated. A comparison of table 4 with table 5, the water budget for 1982 in this projection, gives an indication of such model limitations. Increasing pumpage by 12,400 acre-feet per year has increased the projected downward leakage to unit 2 from 6,750 acre-feet to 14,350 acre-feet during 1982. This doubling of downward leakage, however, may not be hydrologically possible under natural conditions. In addition, underflow into and out of the area has been held constant at steady-state rates for predictive purposes; future stresses could result in raising or lowering these rates. 


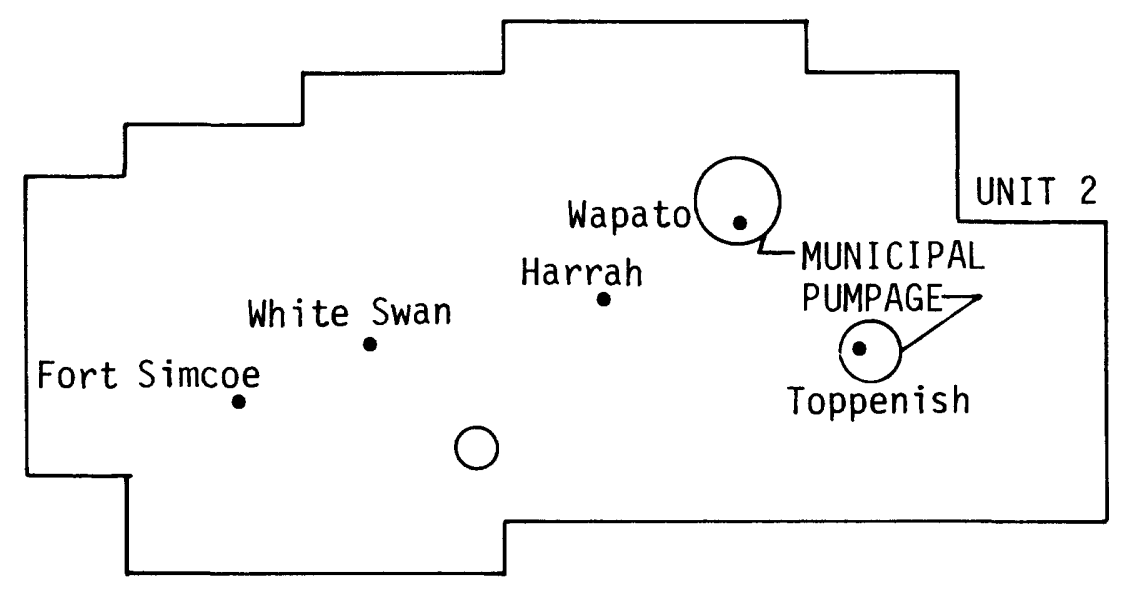

\section{EXPLANATION}

Pumpage, in acrefeet per year

- 100

O $\quad 100-500$

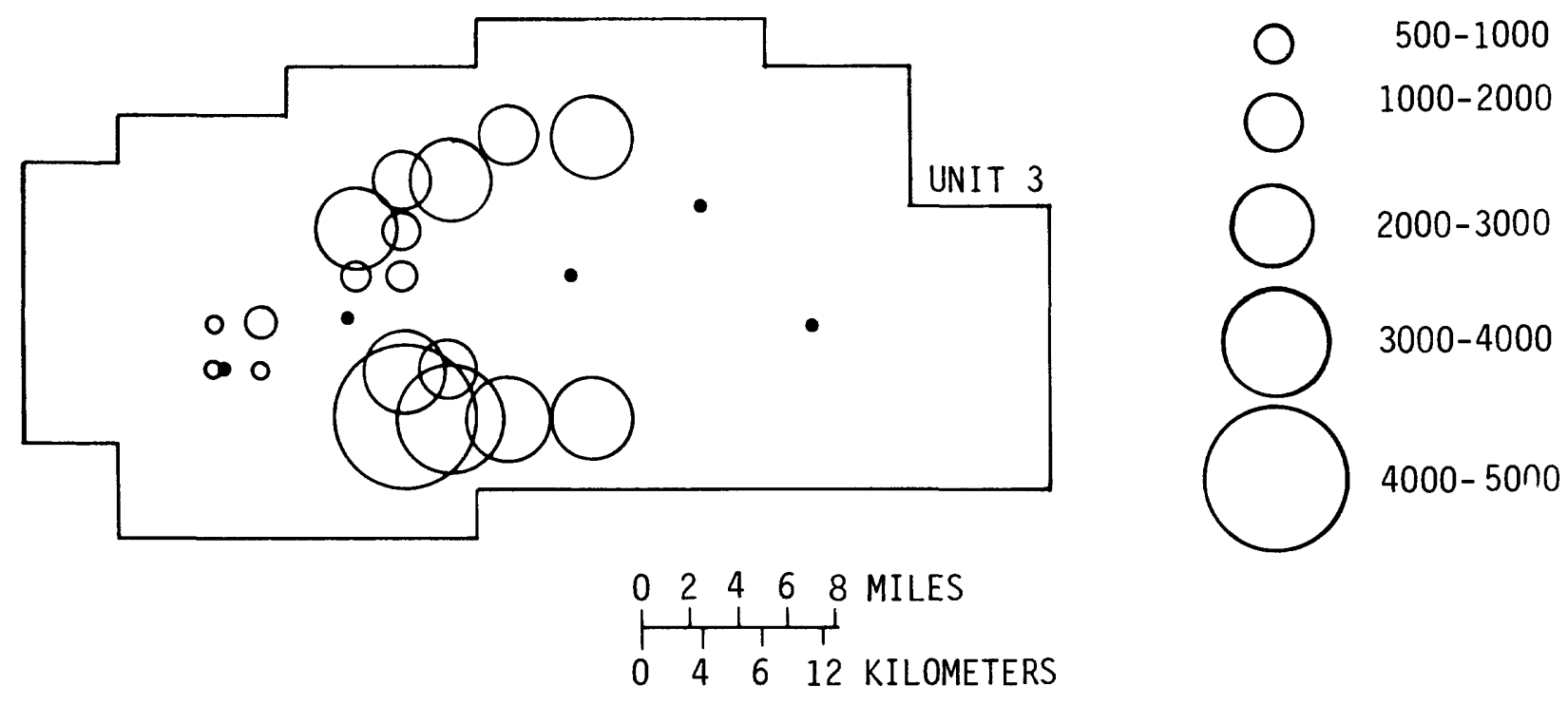

FIGURE 21.--Hypothetical pumping distribution, increasing 1971-72 average pumping by 12,400 acre-feet. 

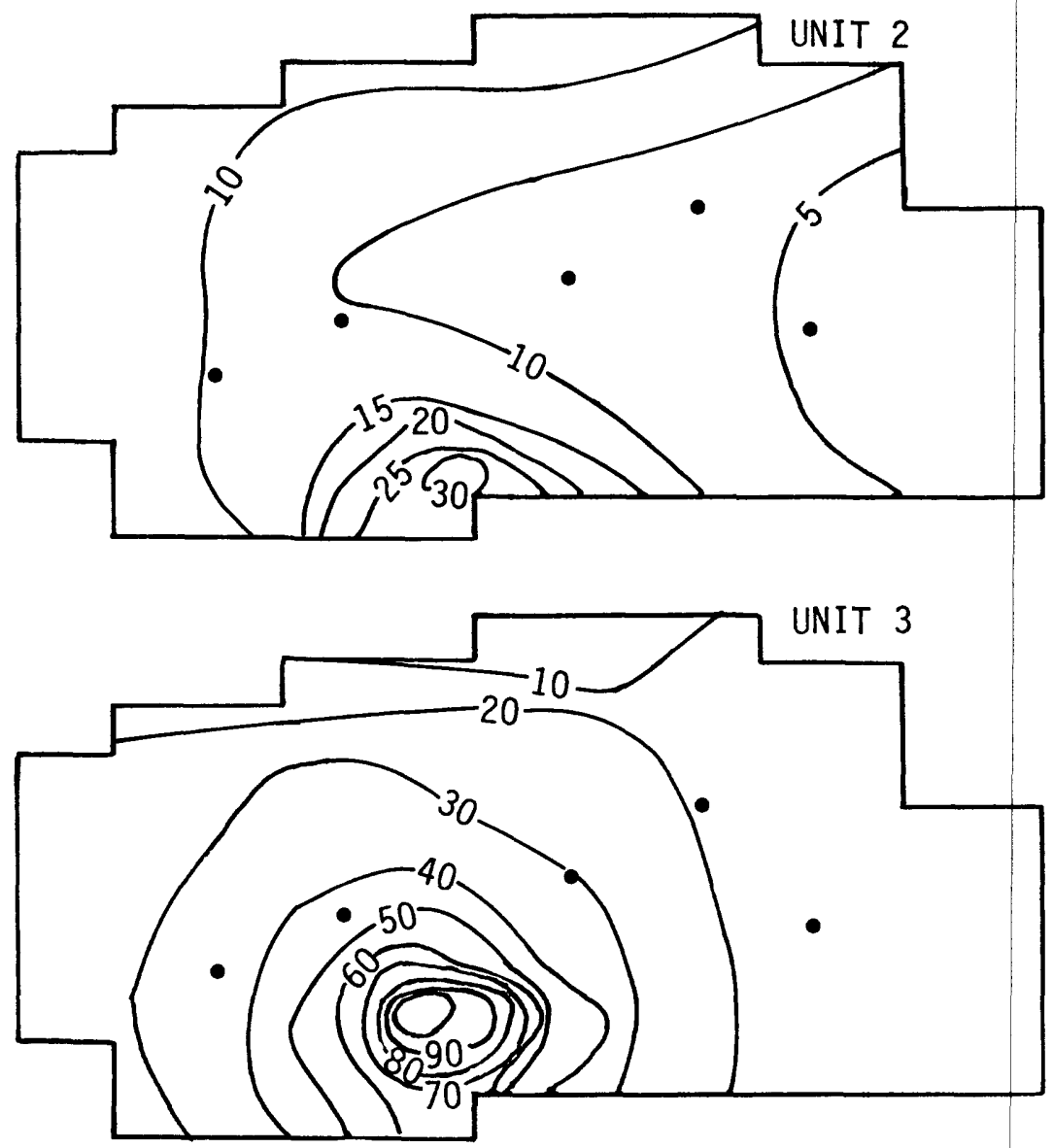

EXPLANATION

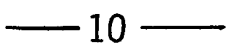

Line of equal head decline. Interval variable, in feet.

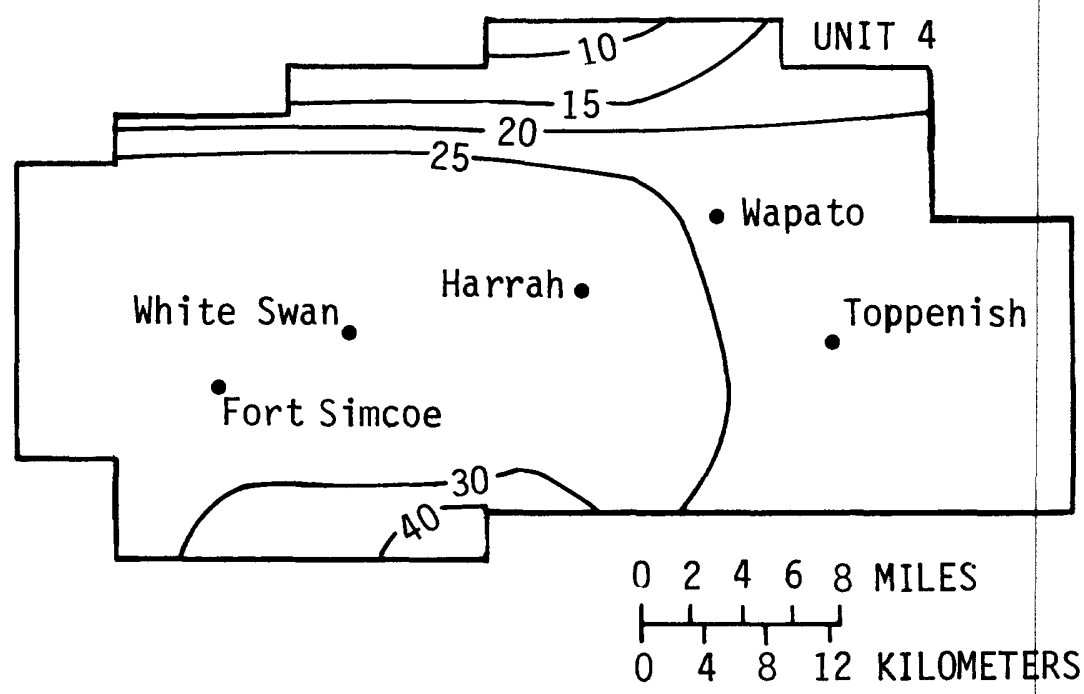

FIGURE 22.--Projected head decline from 1978 through 1982 in units 2, 3, and 4, using 1971-72 average annual pumpage plus 12,400 acre-feet per year. 


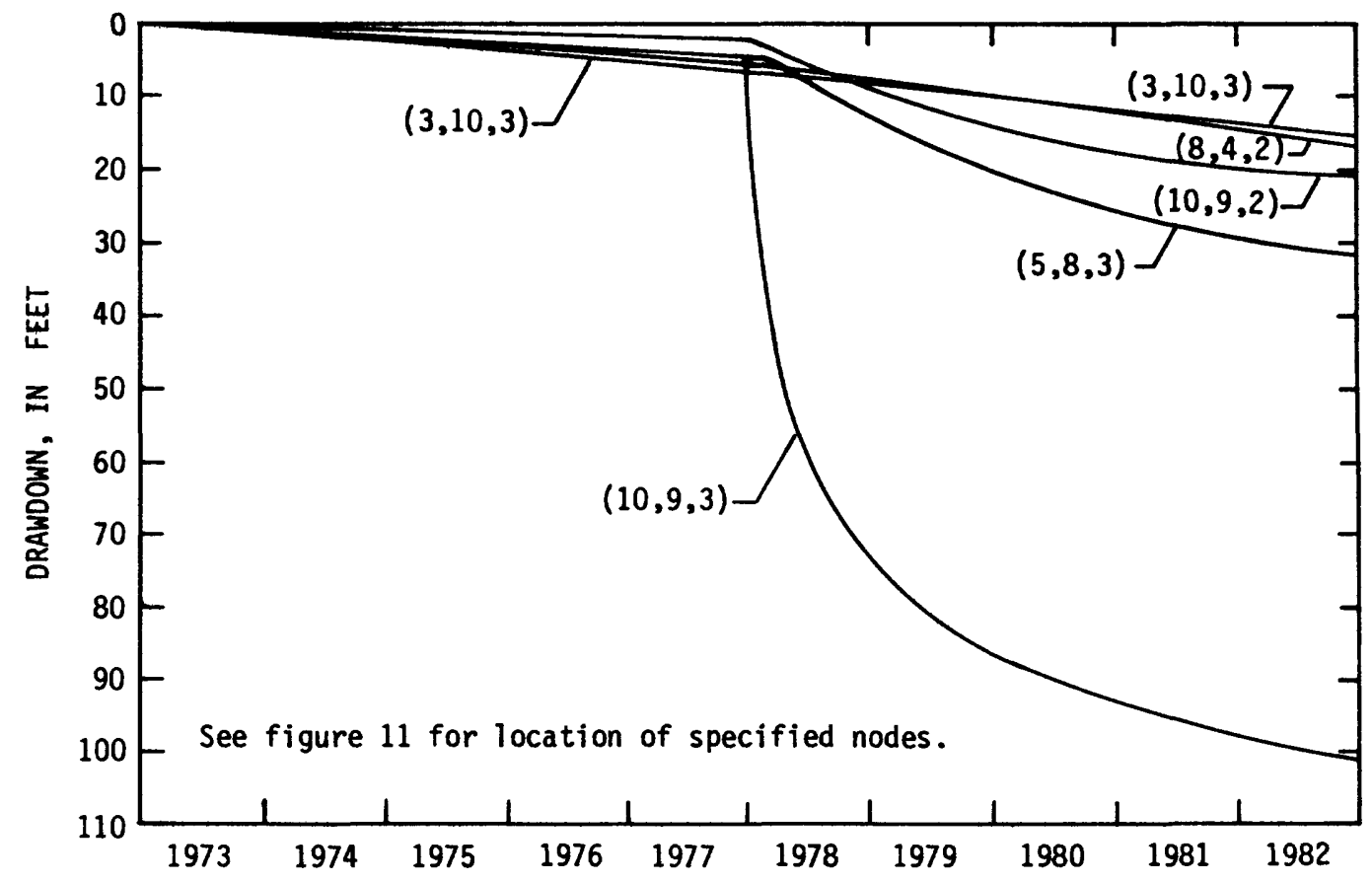

FIGURE 23.--Projected drawdown from 1973 through 1982 at selected nodes, using 1971-72 average annual pumpage plus 12,400 acre-feet per year from 1978 through 1982.

TABLE 5.--Projected water budget for units 2, 3, and 4 for 1982, using 1971 to 1972 average annual pumpage plus 12,400 acre-feet per year from 1978 through 1982

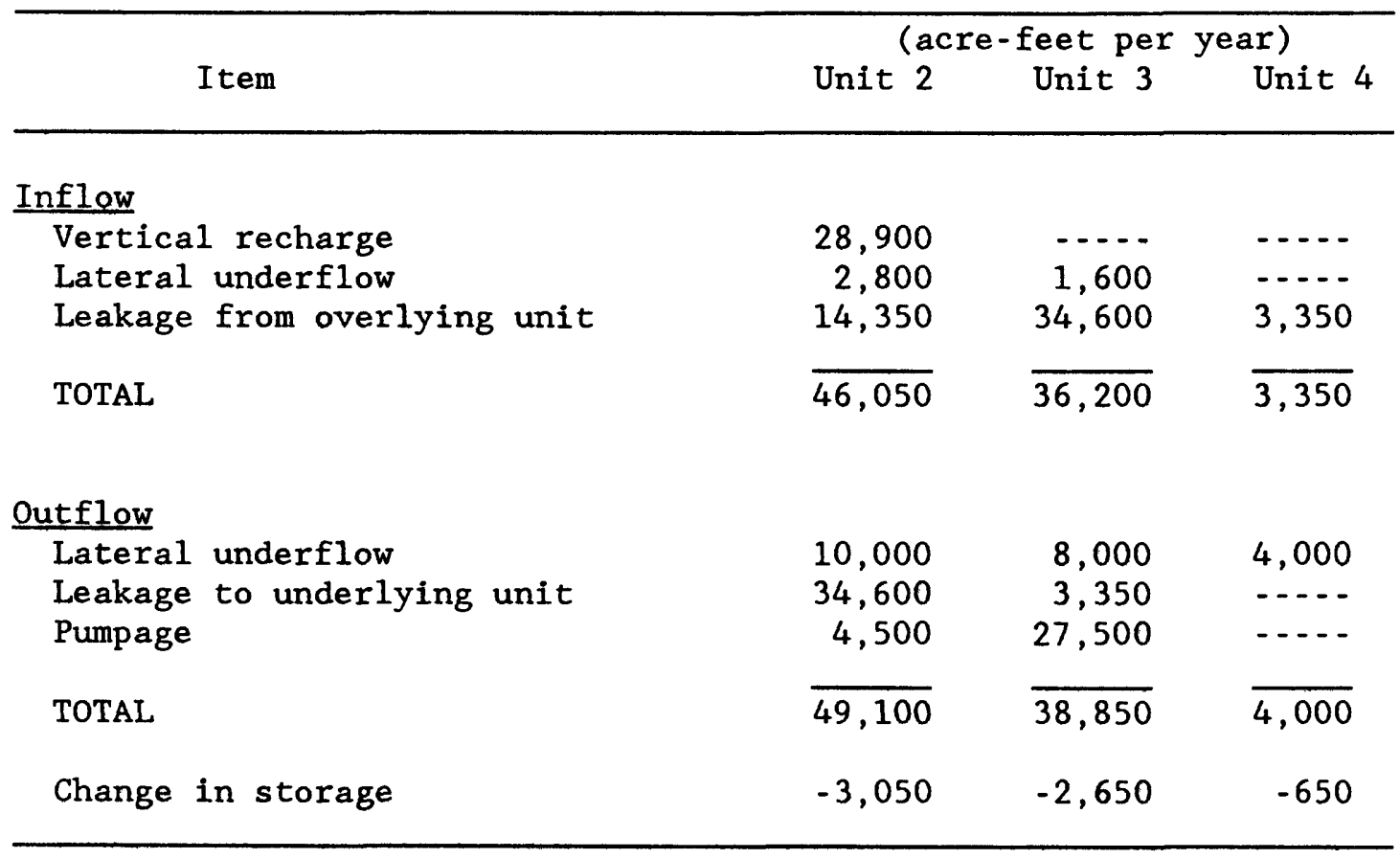




\section{SUMMARY}

A finite-difference ground-water model has been constructed and calibrated for the Toppenish Creek basin aquifer system. Four aquifer units are recognized in the basin: (1) unconfined young valley fill; (2) confined old valley fill and shallow basalt; (3) primary basalt; and (4) deep basalt. The modeled units include units 2,3 , and 4; water levels in unit 1 were held constant with time, but vertical leakage was simulated between units 1 and 2 .

The ranges in calibrated transmissivities for units 2 , 3 , and 4 were from less than 0.01 to $0.10 \mathrm{ft} / \mathrm{s}$, from less than 0.01 to $0.20 \mathrm{ft}^{2} / \mathrm{s}$ and from less than 0.01 to $0.48 \mathrm{ft}^{2} / \mathrm{s}$, respectively. Smallef transmissivities were used on the northern, western, and southern boundaries of units 2,3 , and 4 to simulate less permeable material and (or) less saturated thickness. In addition, lower transmissivities were used in the west-central part of unit 2 to simulate the reduced transmissivity due to an inferred ground-water barrier.

Calibrated storage coefficients for units 2,3 , and 4 were 0.002 to $0.006,0.002$, and 0.0004 , respectively. The callbfated leakance $f 8^{r m s}$ between

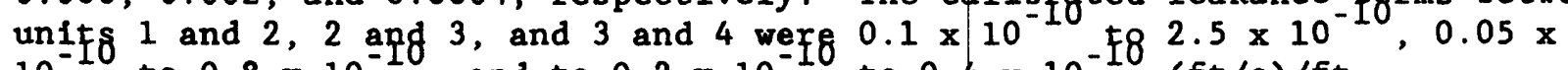
$10^{-10}$ to $0.8 \times 10^{-10}$, and to $0.2 \times 10^{-10}$ to $0.4 \times 10^{-18}(\mathrm{ft} / \mathrm{s}) / \mathrm{ft}$, respectively.

The computer model used was a three-dimensional finite-difference program. The calibration process involved a steady-state analysis (1954 conditions) and transient-state analysis (1955 to 1972). Aquifer parameters were varied to allow better matching of measured and computed heads.

Under steady-state conditions, when pumpage from unit 3 was less than 500 acre-feet per year, natural recharge of about 28,900 acre-feet per year infiltrated to unit 2 , mostly from precipitation and primarily in the western part of the basin. Another 4,400 acre-feet per year entered the aquifer system as underflow from adjacent basins. Discharge under steady-state conditions was by means of underflow out of the basin to the east.

The transient-state calibration period was 1955 to 1972 , over which time pumpage from unit 3 increased about tenfold. The average annual pumpage in 1971 to 1972 was about 15,100 acre-feet from unit 3 and 4,500 acre-feet from unit 2. The simulated decline in unit 3 from 1960 to 1970 , the period of most intense pumpage, was as great as 60 feet in the middle part of the basin.

The calibrated model can be used to predict future water levels due to arbitrary pumping rates, assuming the recharge-discharge relations found during calibration persist in the future. One projection was made for 1973 to 1982 by using the 1971 to 1972 average annual pumpage. The predicted annual declines from 1973 to 1977 in the center of the basin were 0.1 to 1.5 feet in unit 2 and 0.2 to 1.5 feet in unit 3. The annual declines from 1978 to 1982 were 0.1 to 1.2 feet in unit 2 and 0.2 to 0.8 foot in unit 3 . 
Another projection was made by using 1971-to-1972 average annual pumpage plus an additional 12,400 acre-feet pumped from unit 3 from 1978 through 1982 . The simulated annual decline from 1978 to 1982 was 1 to 6 feet in unit 2 and 4 to 20 feet in unit 3 . These results should be considered as only general

because of the large increase in pumpage compared to that used in calibration.

The digital model of the Toppenish Creek basin aquifer system is a simplification of a complex flow system, but it can be used to give generalized indications of the effects of proposed management alternatives. 
Barker, R. A., 1979, Computer simulation and geohydrology of a basalt aquifer system in the Pullman-Moscow basin, Washington and Idaho: Washington Department of Ecology Water-Supply Bulletin 48, 119 p.

Barker, R. A., and Mac Nish, R. D., 1976, Digital model of the gravel aquifer, Walla Walla River basin, Washington and Oregon: Washington Department of Ecology Water-Supply Bulletin 45, 49 p.

Bolke, E. L., and Skrivan, J. A., 1981, Digital-model simulation of the Toppenish alluvial aquifer, Yakima Indian Reservation, Washington: U.S. Geological Survey Water-Resources Investigations 81-425, 34 p.

Bredehoeft, J. D., and Pinder, G. F., 1970, Digital analysis of areal flow in multiaquifer ground-water systems: a quasi three-dimensional model: Water Resources Research, v. 6, no. 3, p. 883-888.

Central Washington State College, 1976, Resource atlas of the Yakima River basin counties: Central Washington State College, 21 plates.

Foxworthy, B. L., 1962, Geology and ground-water resources of the Ahtanum Valley, Yakima County, Washington: U.S. Geological Survey Water-Supply Paper 1598, 100 p.

Gregg, D. O., and Laird, L. B., 1975, A general outline of the water resources of the Toppenish Creek basin, Yakima Indian Reservation, Washington: U.S. Geological Survey Open-File Report 75-19, 37 p.

Hulet, J. C., 1969, Grazing resources inventory, Yakima Indian Reservation, Washington: U.S. Bureau of Indian Affairs Report, 154 p.

Kinnison, H. B., and Sceva, J. E., 1963, Effects of hydraulic and geologic factors on streamflow of the Yakima River basin, Washington: U.S. Geological Survey Water-Supply Paper 1595, 134 p.

Luzier, J. E., and Burt, R. J., 1974, Hydrology of basalt aquifers and depletion of ground water in east-central Washington: Washington Department of Ecology Water-Supply Bulletin 33, 53 p.

Luzier, J. E., and Skrivan, J. A., 1975, Digital-simulation and projection of water-level declines in basalt aquifers of the Odessa-Lind area, east-central Washington: U.S. Geological Survey Water-Supply Paper 2036, 48 p.

Mac Nish, R. D., and Barker, R. A., 1976, Digital simulation of a basalt aquifer system, Walla Walla River basin, Washington and Oregon: Washington Department of Ecology Water-Supply Bulletin 44, 51 p.

Newcomb, R. C., 1959, Some preliminary notes on ground water in the Columbia River basalt: Northwest Science, v. 33, no. 1, p. 1-18. 
-1961, Storage of ground water behind subsurface dams in the Columbia River basalt in Washington, Oregon, and Idaho: U.S. Geological Survey Professional Paper 383-A, 15 p.

-1965, Geology and ground-water resources of the Walla Walla River basin, Washington-Oregon: Washington Division Water Resources Water Supply Bulletin 21, 151 p.

Pinder, G. F., 1970, A digital model for aquifer evaluation: U.S. Geological Survey Techniques of Water Resources Investigations, Book 7, Chapter Cl, $18 \mathrm{p}$.

Robbins, S. L., Burt, R. J., and Gregg, D. 0., 1975, Gravity and aeromagnetic study of part of the Yakima River basin, Washington: U.S. Geological Survey Professional Paper 726-E, 7 p.

Russe11, I. C., 1893, A geological reconnaissance in central Washington: U.S. Geological Survey Bulletin 108, 108 p.

Smith, G. 0., 1901, Geology and water resources of a portion of Yakima County, Washington: U.S. Geological Survey Water-Supply Paper 55, 68 p.

-.-1903, Description of the Ellensburg quadrangle, Washington: U.S. Geological Survey Geologic Atlas, Folio 86, 7 p.

Tanaka, H. H., Hansen, A. J., Jr., and Skrivan, J. A., 1974, Digital-model study of ground-water hydrology, Columbia Basin Irrigation project area Washington: Washington Department of Ecology Water-Supply Bulletin 40, $60 \mathrm{p}$.

Theis, C. V., Brown, R. H., and Meyer, R. E., 1963, Estimating the transmissivity of aquifers from the specific capacity of wells, in Methods of determining permeability, transmissibility, and drawdown: U.S. Geological Survey Water-Supply Paper 1536-I, p. 331-340.

Trescott, P. C., 1975, Documentation of finite-difference model for simulation of three-dimensional ground-water flow: U.S. Geological Survey OpenFile Report 75-438, 32 p.

U.S. Geological Survey, 1975, Water resources of the Toppenish Creek basin, Yakima Indian Reservation, Washington: U.S. Geological Survey WaterResources Investigations 42-74, 144 p.

U.S. Weather Bureau, 1965, Mean annual precipitation, 1930 to 1957, State of Washington: Portland, Oregon, U.S. Soll Conservation Service, map M-4430.

Walton, W. C., 1970, Ground-water resource evaluation: New York, McGraw-Hill, 664 p.

Waring, G. A., 1913, Geology and water resources of a portion of south-central Washington: U.S. Geological Survey Water-Supply Paper 316, 42 p. 